San Jose State University

SJSU ScholarWorks

Master's Theses

Master's Theses and Graduate Research

1991

\title{
A study of changes from women's sections to features/ entertainment sections in daily newspapers from the 1960s to 1990s
}

Denise A. Franklin

San Jose State University

Follow this and additional works at: https://scholarworks.sjsu.edu/etd_theses

\section{Recommended Citation}

Franklin, Denise A., "A study of changes from women's sections to features/entertainment sections in daily newspapers from the 1960s to 1990s" (1991). Master's Theses. 237.

DOI: https://doi.org/10.31979/etd.9s97-pgpu

https://scholarworks.sjsu.edu/etd_theses/237

This Thesis is brought to you for free and open access by the Master's Theses and Graduate Research at SJSU ScholarWorks. It has been accepted for inclusion in Master's Theses by an authorized administrator of SJSU ScholarWorks. For more information, please contact scholarworks@sjsu.edu. 


\section{INFORMATION TO USERS}

This manuscript has been reproduced from the microfilm master. UMI films the text directly from the original or copy submitted. Thus, some thesis and dissertation copies are in typewriter face, while others may be from any type of computer ñinter.

The quality of this reproduction is dependent upon the quality of the copy submitted. Broken or indistinct print, colored or poor quality illustrations and photographs, print bleedthrough, substandard margins, and improper alignment can adversely affect reproduction.

In the unlikely event that the author did not send UMI a complete manuscript and there are missing pages, these will be noted. Also, if unauthorized copyright material had to be removed, a note will indicate the deletion.

Oversize materials (e.g., maps, drawings, charts) are reproduced by sectioning the original, beginning at the upper left-hand corner and continuing from left to right in equal sections with small overlaps. Each original is also photographed in one exposure and is included in reduced form at the back of the book.

Photographs included in the original manuscript have been reproduced xerographically in this copy. Higher quality $6 "$ " 8 9" black and white photographic prints are available for any photographs or illustrations appearing in this copy for an additional charge. Contact UMI directly to order.

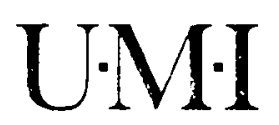

University Microfilms International

A Bell \& Howell Intormation Company 

Order Number 1347152

A study of changes from women's sections to features/entertainment sections in daily newspapers from the 1960s to the 1990s

Franklin, Denise A., M.S.

San Jose State University, 1991 



\title{
A STUDY OF CHANGES FROM \\ WOMEN'S SECTIONS TO FEATURES/ENTERTAINMENT SECTIONS \\ IN DAILY NEWSPAPERS FROM \\ THE 1960s TO THE 1990s
}

\author{
A Thesis Presented to \\ The Faculty of the Department of Journalism \\ and Mass Communications \\ San Jose State University \\ In Partial Fulfillment \\ of the Requirements for the Degree \\ Master of Science \\ by \\ Denise A. Franklin \\ December, 1991
}


APPROVED FOR THE DEPARTMENT OF JOURNALISM

AND MASS COMMUNICATIONS

Stephen Theme

Dr. Stephen Greene

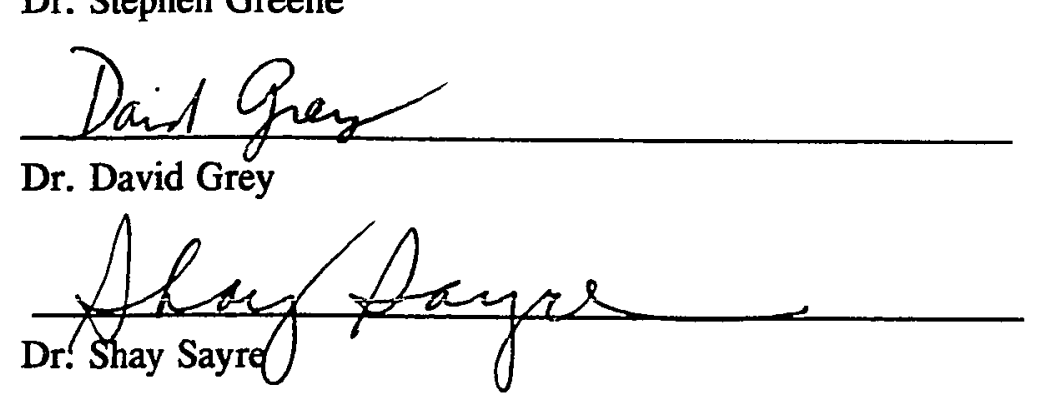

APPROVED FOR THE UNIVERSITY

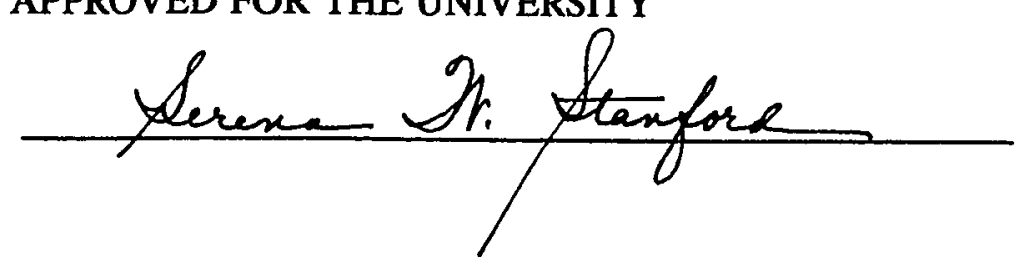




\title{
ABSTRACT \\ A STUDY OF THE CHANGES \\ FROM WOMEN'S PAGES TO FEATURES/ENTERTAINMENT SECTIONS IN DAILY NEWSPAPERS FROM \\ THE 1960S TO THE 1990S
}

\author{
by Denise A. Franklin
}

This thesis examines the changes in content over time in newspaper "feature" sections. Four major daily newspapers were analyzed, The New York Times, Washington Post, Chicago Tribune, and Los Angeles Times. The type of articles, advertisements and photographs printed in these newspapers during four weeks in 1989 were compared to what was printed 1965 and 1975.

The results indicate that from 1975 to 1989 these sections had grown in size, were targeting male and female readers, and had increased in entertainment, syndicated, and political and other non-traditional feature articles. They also showed a decrease in lifestyle articles and in articles about personal relationships, finances and purchases, fashion, and social events. There also was a decrease in content directed at women. 
TABLE OF CONTENTS

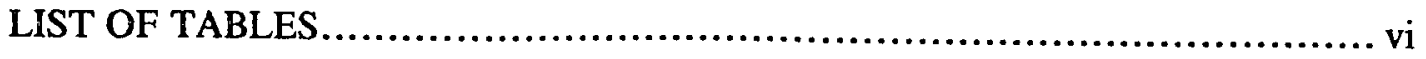
CHAPTER I

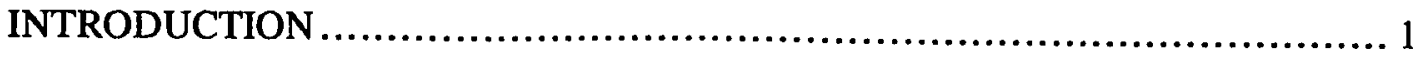

CHAPTER II

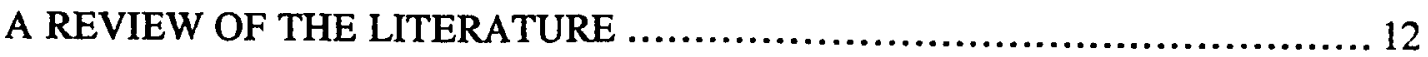

Studies Completed on "Women's Pages" and "Lifestyle Sections" ............ 12

Criticism and Analysis of "Lifestyle Sections" ................................ 20

CHAPTER III

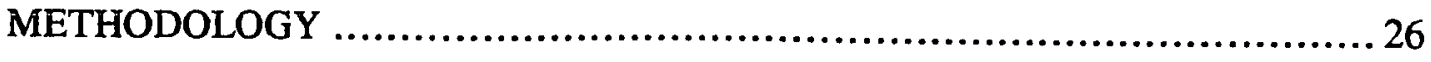

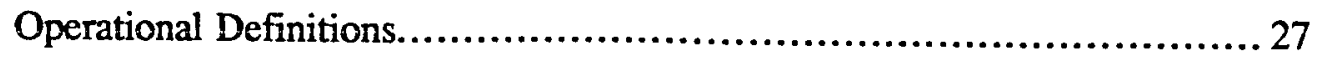

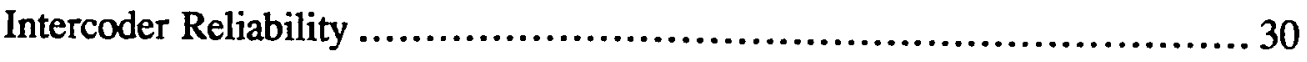

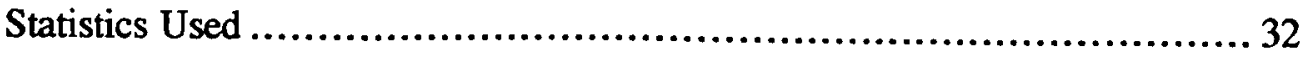

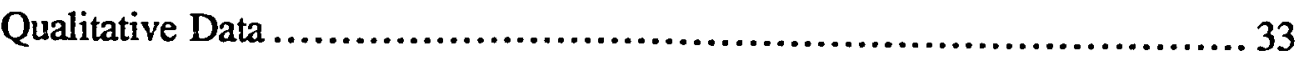

CHAPTER IV

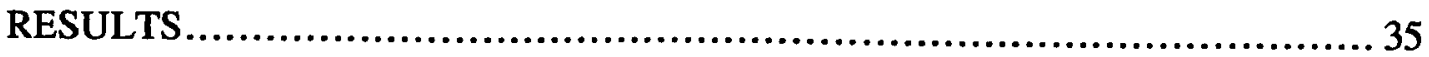

"Feature Sections" Increase in Size ........................................... 35

Changes In Types of Articles................................................ 43

Changes In Emphasis on Gender ............................................. 54

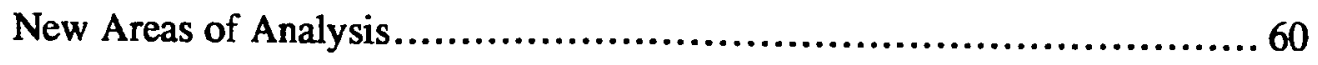

CHAPTER V

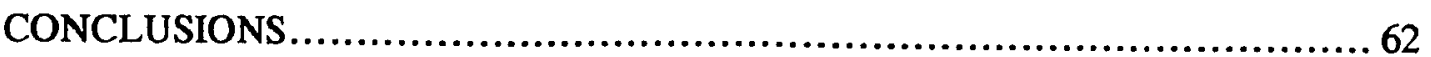

Directions for Further Research ........................................ 66

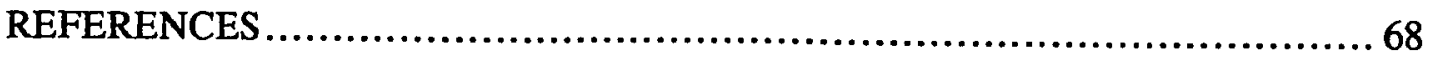




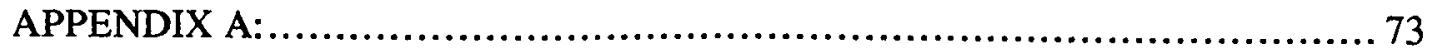

Chi Square Tables and Results Showing Significant Differences Over

Time Across Newspapers and Over Time in Individual Newspapers ................ 73 


\section{LIST OF TABLES}

1. Daily Newspaper Audience On An Average Weekday .......................6

2. Percentages of Readers by Gender Who Usually Read Lifestyle Content......... 8

3. Units of Observation ..................................................... 31

4. Percentages of Stories by Content Category .................................. 36

5. Average Number of Lifestyle Pages Per Week ................................ 37

6. Average Number of Stories Per Page ..................................... 38

7. Average Number of Photos Per Page......................................... 39

8. Average Number of Ads Per Page ............................................ 39

9. Percentages of Number of Stories Within Content Categories.................. 45

10. Percentages of Articles by Gender....................................... 55

11. Percentages of Photos by Gender ........................................ 57

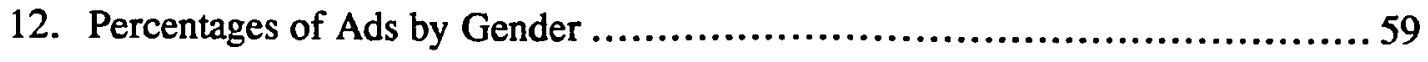

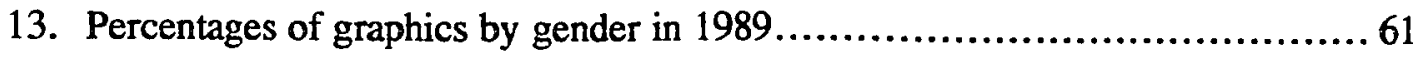




\section{CHAPTER !}

\section{INTRODUCTION}

What once were called "Women's Pages" in daily newspapers have evolved over the last 25 years into what were known as "Lifestyle Sections" and then into what today Miller (1990) calls "Features/Entertainment Sections." These sections have developed new content and new names. Yet there is little evidence of how they have changed. Few studies have been done since the 1970s, when a flurry of research examined the evolution from "Women's Pages" to "Lifestyle Sections" (e.g., American Association of University Women, 1974; Guenin, 1975; Baca; 1975; Miller, 1976; Merritt \& Gross, 1978). There is a need for more study of what has occurred to these sections since they were known as "Women's Pages" in the mid-1960s.

The "Features/Entertainment Sections" which replaced "Lifestyle Sections" in the early 1980 s were a reaction to newspaper managements' concerns that household penetration was declining and young people, in particular, weren't reading newspapers like they did in the past (Miller, 1990). When newspapers say they are going after the youth market, they are talking about 18-24 year olds, and occasionally about those under 30, according to Al Gollin, vice president and research director for the Newspaper Advertising Bureau (personal communication, July 18, 1991). The thought in the early 1980s was to focus daily theme pages at different age groups, and to reach the youth market with more entertainment articles.

Where these sections will go in the future depends on what segment of the population newspapers attempt to attract. In the early 1990s, there appears to be a growing concern about the loss of women readers. Some newspapers are gearing themselves toward the baby-boomer market, which includes those born between 1946 
and 1964. There also is concern over attracting the under-30 readers (American Seciety of Newspaper Editors, 1991), which again goes back to the effort to attract the youth market. These readers fall into two groups: they are either at risk of dropping their newspaper reading habit or they simply are not reading the newspaper as much as they should be.

Miller advocates "Feature sections" going after baby-boomer women (personal communication, July 3, 1991). They should be full of articles on saving time, balancing multiple roles, reducing stress, and getting through life with quality and sanity, according to Miller. She said:

The issue today is: If you want to do all these things, how do you stretch yourself? The issue is of time, rather than of choices. It's appropriate to have a new definition of what should be in the feature section. If newspapers do not provide it, they will go out of business because they will be irrelevant (personal communication, March 1, 1989, July 3, 1991).

A study of these sections could provide information to help editors formulate this new definition. Such a study could determine if today's "Features/Entertainment Sections" are offering the type of content suggested by Miller. It could show whether "Features/Entertainment Sections" are retuming to some of the traditional content editors dropped in the 1960s. It could show whether newspapers are gearing these sections toward women, toward the under-30 market, or toward to those between 18 and 24 . Such a study could be quantitative, taking a look at contemporary content compared to the 1960 s and 1970 s. It could also find out what "Features/Entertainment Section" editors say about how their sections have changed, what their sections are today, and what the sections will become in the future. 
Several reasons exist why a study is needed. An absence of recent studies makes it difficult to define what a "Features/Entertainment Section" is today and where it should be going in the future. There appears to be renewed interest in women's news in these sections, with the American Society of Newspaper Editors sponsoring two prototype women's sections in both 1990 and 1991 . There also appears to be interest in gearing these sections to young, two-worker families with children at home. The American Society of Newspaper Editors (1991) commissioned a prototype "Feature Section" for young parents and children.

Also, studies in the 1970s indicated that the content of "Lifestyle Sections" had not changed much from the "Women's Pages" (e.g., Baca, 1975; Guenin, 1975; Miller, 1976; Merritt \& Gross, 1978). Study is needed to determine whether there really have been major changes in these sections since the mid-1970s. Finally, there seems to be confusion over what these sections are today and where they are going. A study could provide some answers. As McGhee (1988) said:

Lifestyle sections . . . have spent the last decade or so adjusting here, slicing up there, but also losing focus, mushing up the mission. It is time for another fundamental rethinking. (p. 11)

These sections appear to the back of the daily newspaper, behind the hard news sections. They consist of soft news or features compared to the hard, breaking stories of the news section. Attempts were made in the past to define the actual content of these sections. Guenin (1975) came up with a consensus of lifestyle editors from six newspapers that traditional content found in "Women's Pages" included advice, astrology, beauty, marital news, charity benefits, clubs, fashion, food, home furnishings, and society events. Miller (1990) noted that the traditional "Women's 
Section" contained articles on child-rearing, home care and furnishings, finances and purchases, as well as recipes, parties, and brides.

After talking with various critics, writers, and women's editors, Guenin (1975) found no consensus about what should be in new "Lifestyle Sections." Therefore, the suggested list contained many topics: adolescence, aging, children, community improvement (including environmental stories), consumerism, economics, editorials and letters, education, employment, equality movement, family, hobbies, housing, humor, legal problems, marriage, medicine, mental health, minority news, population control, single life, transportation, volunteer services, and working women. Miller (1976) stated the dominant philosophy covering the change was "that the women's pages should become lifestyle sections focusing on both men and women, and dealing with the concerns of average citizens, such as consumer topics and changes in male and female roles" (p. 641). These sections, according to Miller (1990), covered more "ordinary people" and "human interest" stories, contained news about clubs only when they did something newsworthy, and still carried recipes and diet tips.

It is more difficult to find a definition of the "Features/Entertainment Section" of the late 1980s and early 1990s since it is relatively new. Miller (1990) stated these sections are aimed at target audiences of various ages. Particular emphasis is given to young adults by providing more entertainment and leisure coverage. Some newspapers have combined their lifestyle and entertainment coverage into one section. Some editors are more interested in covering arts and entertainment in these sections, and others are confused about their mission, Miller stated (1990). "The result - deliberate or otherwise - has been a general de-emphasis of lifestyle coverage, news you can use, and other topics of particular interest to women" (p. 4). 
The changes in these sections reflect changes in society. In the $1960 \mathrm{~s}$, the "Women's Pages" reflected the traditional lifestyle of most women, according to Miller (personal communication, March 1, 1989). Women tended not to work outside the home. They were interested in getting married, their appearance, being involved in charity benefits, clubs and society events, and in creating attractive meals and a comfortable home for their families, Miller said. In the late 1960 s and 1970s, there was disruption in traditional society. Women, Miller said, were saying, "I know what I said when I married you, but I've changed my mind." The section, renamed "Lifestyle," reflected this era with a hard-edged, confrontation style, according to Miller.

This "disruption in traditional society" is more commonly called the women's liberation movement. Women's status began to change dramatically in the mid-1960s. In 1966, the National Organization for Women (NOW) was organized (Zophy \& Kavenik, 1990). The women's liberation movement flourished in the late 1960s and early 1970 s as a variety of independent groups throughout the U.S. In 1963, the Equal Pay Act was passed, requiring employers to pay male and females the same wages when they performed jobs that entailed equal skill, effort, and responsibility. Discrimination in employment on the basis of race, color, religion, national origin, or sex was forbidden by Title VII of the Civil Rights Act of 1964. In 1967, NOW endorsed a federal Equal Rights Amendment, and in the decade following, it came close to passing. The ERA needed to be ratified by 38 states, and 35 approved it. Also at this time, under pressure from the feminist movement, a number of states liberalized their laws on abortions. Some states began allowing abortions for other reasons than the endangerment of a woman's life or physical well-being. In 1973, the Supreme Court decision Roe vs. Wade struck down all state laws prohibiting abortion 
on any grounds during the first trimester of pregnancy. As women challenged the traditional definitions of womanhood, newspapers began revamping their traditional "Women's Pages" to reflect the changing times.

However, these changes were not attracting readers; they may have had something to do with the continuing decline of newspaper readership by women. As shown in Table 1, the number of women who read newspapers is falling at a greater rate than the number of male readers (Simmons, 1990). The decline in average weekday readership over the past three decades began in 1973, and has remained fairly consistent through the years (Simmons, 1990).

\begin{tabular}{|llll|}
\hline \multicolumn{3}{c}{ Table 1 } \\
Daily Newspaper Audience On An Average Weekday \\
\hline Gender & 1967 & 1990 & Change in readership \\
\hline Males & $75 \%$ & $65 \%$ & $-7.5 \%$ \\
Females & $76 \%$ & $61 \%$ & $-11.4 \%$ \\
\hline Note. From "Study of Media and Markets," 1990, \\
\hline Simmons Market Research Bureau.
\end{tabular}

Another study by the National Opinion Research Center (Wood, 1989) showed that the percentage of women who read a paper daily dropped from 1972 to 1989 by $25 \%$, while daily readership by men has dropped $29 \%$. But even this data indicates fewer women are reading newspapers on a daily basis than men. In every year except 
1977 , the percentage of women reading newspapers on a daily basis was less than that of men. In 1977, the percentages were basically equal.

Still another study by the Newspaper Advertising Bureau (1988) found that in $1987,52 \%$ of men considered themselves frequent readers of newspapers, while only $48 \%$ of women characterized themselves this way. Women also constituted the majority of infrequent readers (58\%) and nonreaders (55\%).

Readership by women should be going up, not down. Women make up the majority of the U.S. population and will continue to outnumber men well into the next century (Spencer, 1984). As Miller noted:

If the balance of contents in newspapers were just right, the percentage of women reading newspapers and the percentage of men reading newspapers as a percentage of the population ideally would be $60 / 60$. What we have right now is about $64 \%$ of all adult men and $60 \%$ of all adult women, so there is a $4 \%$ gap (personal communication, July 3, 1991).

Newspapers are losing female readers, the very readers who tend to read the "Features/Entertainment Section" (Table 2). Instead, women are turning to magazines, a trend expected to continue, according to a study by the Human Affairs Research Centers of the Battelle Institute (1987). "We may have thrown the baby out with the bath water when we stopped women's sections 25 years ago. That area was taken over by the women's magazines," said Nancy Woodhull, president of Gannett News Service and New Media (Meyers, 1990, p. 57).

Women today tend to work outside the home, according to the Battelle Institute study (1987), which made projections through the year 2000. As of 1990 , the majority of women 25-54 would be working outside the home. The largest category of these workers, some $41 \%$, would be mothers working outside the home. Women also are 
better educated than they were in the early 1960 s when newspapers were publishing "Women's Pages" full of traditional content such as marital news, charity benefits, club news, and society events. Between 1960 and 1980, the average time women spent in college rose from 1.4 to 2.6 years. By 1980 , women's enrollment in college was higher that of men for ages 18-19. Women also have less leisure time, meaning they probably have less time to read the newspaper.

\begin{tabular}{|lll|}
\hline \multicolumn{3}{|c|}{ Table 2 } \\
Percentages of Readers by Gender Who Usually Read Lifestyle Content \\
\hline Type of content & Women who read & Men who read \\
\hline Advice columns & 73 & 43 \\
Supermarket ads & 73 & 40 \\
Food pages & 72 & 35 \\
Fashion and lifestyle & 67 & 26 \\
Crossword puzzle & 29 & 22 \\
Celebrity news & 74 & 56 \\
\hline Comics/funnies & 56 & 60 \\
\hline Note. From "News and Newspaper Reading Habits, ${ }^{n}$ Newspaper & \\
\hline Advertising Bureau, 1988, p. 39. & & \\
\hline
\end{tabular}

Women are working outside the home, they are taking care of families, they have less time to read (Abarbanel \& Peterson, 1989), and they are turning to magazines while turning away from newspapers. In 1990, close to 84 million women in the U.S. 
read an average of 11.2 magazines a month, up from 10.3 magazines in 1989, according Spring 1991 Mediamark Research Inc. data given by Chantan Shah, account services executive with Mediamark Research Inc. (personal communication, July 15, 1991). In the same year, 53.5 million women read a daily newspaper on an average weekday, Shah stated. This is down from the 57 million women in 1989 (Simmons, 1990).

New women's magazines have started in competition with established women's magazines such as Better Homes and Gardens and Good Housekeeping. These new magazines gained female readers between 1980 and 1988, according to Simmons Market Research Bureau data (as cited in Media Industry Newsletter, 1989). At the same time, daily readership of newspapers by women fell from $65 \%$ in 1980 to $62 \%$ in 1989 (Simmons, 1990).

The trend in these sections beginning in the early 1980 s was not to focus on women readers, but to attract the youth market (Miller, 1990). As editors realized that household penetration was steadily dropping and young people in particular were not reading newspapers, they changed the sections from "Lifestyle Sections" to "Features/Entertainment Sections." "In particular, the emphasis was on reaching young adults with more entertainment and leisure coverage," Miller stated (p. 4). What got lost was the fact that they are read mainly by women (Newspaper Advertising Bureau, 1988). As Miller noted:

If you want to be utterly practical, you go where the population is. You ask yourself: Where do I want to be in 10 years? Where will the bulk of the population be in the next 10 years? You don't go after young people because their population is decreasing. Where you want to go is after the baby-boomer 
market, people born between 1946 and 1964 . You should be going after babyboomer women in particular (personal communication, July 3, 1991). In suggesting ways newspapers can improve content to entice women readers, Miller (1989) stated they should include content aimed at helping working mothers balance multiple roles. "We can help them figure out how to balance the various parts of their lives with regular (at least weekly) features on housekeeping and shopping tips, managing their careers, and parenting," she stated (p. 18). She further suggested increased time-saving tips and information about time-saving services; increased content about child rearing and family relationships; increased content about home remodeling, home decorating, home entertaining, gardening, and landscaping; and increased "news you can use" such as consumer tips and buying information. She also called for an increase in content for young women because they are needed to replace older readers. "Topics of special appeal to younger women include regular coverage of aerobics and fitness, fashion, relationships, and other topics targeted by women's magazines" (p.19).

Study is needed to determine just what kind of content "Features/Entertainment Sections" are providing their readers today, and if this is the type of content that will add readership to these sections into the future. The following was inspired by Miller's (1976) comparison of 1965 "Women's Pages" and 1975 "Lifestyle Sections." It takes Miller's data and adds comparable data from 1989 "Features/Entertainment Sections" in the same four major U.S. dailies Miller studied. This 1989 data shows how these sections have changed over time, but does not show what is happening to these sections in the 1990s. Nor does it indicate what will occur with them in the future. In order to make this study relevant to the 1990s, it includes interviews completed in May of 1991 
with editors of "Features/Entertainment Sections" throughout the United States. This study suggests future areas of research. 


\section{CHAPTER II}

\section{A REVIEW OF THE LITERATURE}

Studies Completed on "Women's Pages" and "Lifestyle Sections"

The few studies done on the changes from "Women's Pages" to "Lifestyle Sections" were completed in the mid-1970s and early 1980s. The rest of the literature appearing in magazines, newspapers, and books consists of critical analysis and opinion as opposed to research.

At least five studies of "Women's Pages" and "Lifestyle Sections" were completed in the 1970s. Study groups of the Beaverton and Portland, OR chapters of the American Association of University Women (1974) completed a content analysis of three months of "Women's Pages" in the Portland Oregonian. These researchers noted that newspapers nationwide were avoiding "Women's Pages" where women's news was placed away from the rest of the paper. They wanted to find out what was happening with the former "Women's Pages," renamed "Day," in the largest daily newspaper in their area. Guenin (1975) compared the content of traditional women's pages with the new, nontraditional sections in six newspapers. Baca (1975) completed a master's thesis on content changes between 1953-1974 in the "Women's Pages" of three San Francisco Bay Area newspapers. Miller (1976) looked at the content changes in "Women's Pages" and "Lifestyle Sections" over a decade in four major U.S. newspapers. Merritt and Gross (1978) studied the content preferences of female and male editors of the new "Lifestyle Sections." Researchers used different definitions of what constituted traditional and non-traditional content, making their findings difficult to compare. 
Baca (1975), in studying the San Francisco Chronicle, Oakland Tribune, and San Jose Mercury over 21 years, found an increase in non-traditional subject matter (features about people, male fashion, other non-traditional features, women/careers/ liberation) and a decrease in traditional subject matter (advice, children, cooking, crafts/art, fashion, social news, romance). But she also found that most of the articles were still traditional, as did Merritt and Gross (1978). This should come as no surprise since Merritt and Gross (1978) also found that both female and male editors of these sections preferred a traditional-style section over the new "Lifestyle Section."

Guenin (1975) concluded that the new non-traditional sections were not doing an adequate job of appealing to both women and men by broadening their content. Guenin (1975) noted that while traditional content had been cut back considerably in papers that had modernized their "Women's Pages" such as the Los Angeles Times, the St. Petersburg (FL) Times, and the Davenport (IA) Times-Democrat, these updated sections were not adequately covering the topics suggested by critics, writers, and "Women's Page" editors. These topics included adolescence, aging, children, community improvement (including environmental stories), consumerism, economics, editorials and letters, education, employment, equality movement, family, hobbies, housing, humor, legal problems, marriage, medicine, mental health, minority news, population control, single life, transportation, volunteer services, and working women. In fact, she found the traditional sections in the Philadelphia Bulletin and in the Arizona Republic covered non-traditional topics at least as well as the non-traditional sections. Miller (1976) agreed with Guenin's (1975) findings in stating that the traditional women's sections of the 1960 s "tended to offer more variety in their coverage than our memories give them credit for. . . . At some papers, there has been more talk than change. And in some instances, the changes have been for the worse" (p. 647). Miller 
(1976) discovered that among The New York Times, Washington Post, Chicago

Tribune, and Los Angeles Times, only The N̦w York Times had substantially increased the amount of lifestyle and consumer coverage from 1965 to 1975 . She defined lifestyle coverage as including personal relationships, sex roles, work relationships, and rearing children. She defined consumer stories as including health, home care and furnishings, personal finances, and environment.

The AAUW researchers (1974) concluded that the Portland Oregonian should return to a "Women's Section," but not necessarily one with traditional content. They called for a section that "should increasingly concentrate on relevant, honest, and hard hitting descriptions of the lives, contributions and needs of Oregon women" (p. 11). They came to this conclusion after their quantitative study of the new "Day" section (now called "Northwest Living"). Their study found that the largest amount of news in the "Day" section from August-October 1973 was general news not about women. This was followed by entertainment, feature articles about women, food and household advice, styles, advice, community meetings and events about women, community meetings and events not about women, family news, gossip and society, general health, women's health, and straight news about women. In noting that general news not about women was the largest category in the "Day" section besides advertising, the researchers asked, "How much news of the productivity, contribution and real newsworthy activity of Oregon women had to be dumped to allow for these news items?" (p. 8). They concluded that for the interim period:

Women should turn back to newspaper sections reserved exclusively for them, sections which resist the evident erosion of women's space as a dumping spot for all the miscellany which is not absorbed in other parts of the paper. It is our inescapable conclusion that the women of the Portland metropolitan community 
could better be served by having a section of the newspaper clearly defined for themselves and that carefully selected, fairly-allocated space dealing with women's lives and activities would be more realistically represent the part women play in our northwest world. (p. 11)

What may have been occurring in the mid-1970s was not a change to a "Lifestyle Section," but a change to more entertainment news in the former "Women's Pages." The AAUW (1974) study found entertainment came in third behind advertising and non-female general news in the Portland Oregonian's revamped section. AAUW researchers stated, "While entertainment is undoubtedly a sales feature of any newspaper, this committee protests the inclusion of all these entertainment features in the "Day" section at obvious expense to women's hard news" (p. 8). Guenin (1975) found more entertainment stories in the "Lifestyle Sections" over the "Women's Pages." Merritt and Gross (1978) discovered that the non-traditional male editors of "Women's/Lifestyle Sections" had a goal of more entertainment coverage, while their female counterparts preferred emphasizing social change. Miller (1976) found that the percentage of entertainment/arts coverage showed the greatest amount of fluctuation among the four newspapers of any type of coverage.

In Miller's study, she found entertainment coverage increased dramatically in both percentage and number of stories in the Washington Post. The Los Angeles Times, having greatly decreased the size of its "Lifestyle Section," increased the percentage of entertainment stories somewhat, but the number stayed about the same. At The New York Times, the number and percentage remained nearly the same, while coverage actually went down at the Chicago Tribune. She also discovered that while the "Lifestyle Sections" at all four papers were shrinking in size, separate "Entertainment Sections" were growing. 
Researchers also documented a loss of society coverage. The AAUW study (1974) found that gossip and scciety news took up less than $1 \%$ of the sections in most cases and that so-called family news (weddings, engagements, births, anniversaries, obituaries) also was allocated less than $1 \%$ of the space. The researchers stated:

We applaud the Oregonian for its shrinkage in coverage of limited-appeal news: weddings, engagements, and the like. Since a Lou Harris poll reports that weddings readership stands at $3 \%$, it seems justifiable for a newspaper to charge for this ego-massaging space. (p. 10)

Baca (1975) discovered that social news and romance were the two subjects that showed the largest decrease between 1953 and 1974 in the three papers she studied. Guenin (1975) also found that the updated "Lifestyle Sections" had less society news than the traditional "Women's Pages." All four papers that Miller (1976) studied had decreased coverage of social events, along with engagements, weddings, and fashion stories between 1965 and 1975. She noted that in getting rid of some of their traditional baggage, the major U.S. dailies also cut back on stories about child rearing and home care tips for consumers.

Few studies were done after those in the mid-1970s, even though the change from traditional to non-traditional sections was occurring in almost half the newspapers in the U.S., according to Pierce (1980) and Finney (1983). Starting in the 1980s, the "Lifestyle Sections" were changing to "Features/Entertainment Sections" (Miller, 1990), but not much research exists to document this change. The Associated Press Managing Editors Modern Living Committee (1981) surveyed "Living Section" editors. The American Society of Newspaper Editors (1990) sponsored development of a prototype "Women's Section." The following year, the American Society of Newspaper Editors (1991) sponsored another prototype of a "Women's Section" and a 
prototype of a "Features Section" aimed a children and families. In both cases, focus groups were used to analyze the sections.

The Associated Press Managing Editors Modern Living Committee (1981) documented the changes by surveying "Women's/Lifestyle Section" editors. In most cases, the shift from "Women's Pages" to "Lifestyle Sections" meant an increase in news hole. Some 114 of 197 editors (58\%) said their news hole had increased between 1976 and 1981 . Some 124 of 203 editors (61\%) said their newspaper had a greater commitment toward their section. While not providing any statistics, the committee stated:

It is almost universal that weddings and engagements are being down played in today's newspapers. . . . Social news in general has been downgraded although some newspapers have switched to a once-a-week society column in which they're able to make little bullet items out of what used to take two, three, or more paragraphs in the daily newspaper to tell. (p. 4)

Realizing the importance of bringing women readers back to newspapers, the American Society of Newspaper Editors (1990) commissioned the development of "Womenews," a prototype "Women's Section." The following year, the American Society of Newspaper Editors (1991) still found women to be an important target market, coming up with another prototype section for women, "You." Interest in attracting younger readers also was apparent in 1991, with the American Society of Newspaper Editors also coming up with a prototype "Features Section," "Rumpus," geared to two-worker families with children under 18 at home.

The group of newspaper and advertising professionals who chose to target a section at women in 1990 did so not only because women are declining as readers at a 
faster pace than men, but also because women will continue to be important to newspapers. They stated:

By the year 2000, more than 65 percent of the new labor force will be women, and 51 percent of all women of working age will be employed. A large percentage of these women will be new arrivals in the United States with special needs. For the first time, the average person in the United States is a woman. She is: 5' 4" tall; weighs 143 pounds; owns 10 credit cards; has a better education than ever before; is going to live longer; drives an 8-year-old car; has two TVs, six radios, VCR, stereo; carries $\$ 104$ in her purse; drives 10 miles to the office; has one husband, two kids; has been or will be a victim of crime three times in her life; has a 50 percent chance of becoming divorced. Newspapers need to reach the woman described, as well as her growing older sisters, affluent and otherwise, to curb readership declines. (p. 80)

Those who put the prototype together decided that it should be newsy and look strong, recognize subscribers as users as well as readers, be highly organized, recognize that women want to read about other women, include articles relevant to women's lives in the 1990s, understand that women appreciate how difficult and complex it is to have it all, recognize that having it all means different things to different women, and recognize that women are "presidents of themselves" (p 80). Nancy Woodhull, president of Gannett News Services and New Media and member of the prototype committee, stated:

A product such as "Womenews" could stem the proliferation of women's magazines that now try to give women what "Womenews" can do in a more timely fashion. And the women's magazines have been able to do that because newspapers haven't. ... (p. 80) 
The busy working women who made it to two focus group discussions at first were wary about the concept. Even though they felt newspapers tend to present a male point of view, they believed a separate section for women would result in a separatebut-not-equal treatment of serious news about women. But after seeing the prototype, the women tended to approve. They found the section presented news in a way that they could find it quickly, addressed common bonds among women, took women seriously, covered the women's angle of major news stories, and contained useful information and interesting leisure-time reading. They also pointed out how it could be improved. They said it was aimed too much at women baby boomers, that some stories lacked depth, that any hint of "fluff" should be eliminated from the front page, and that the name should be changed. Woodhull noted: "Any name with woman in it still may have more downside risk than upside potential, given people's memories of what women's sections were historically" (p. 82).

The American Society of Newspaper Editors (1991) took a look at how to entice at-risk readers (those who read the paper up to four times a week but find little value in it) and potential readers (those who occasionally read papers, but do not consider them a good source of knowledge on current events). The society asked the Lexington Herald-Reader to develop a section to appeal to at-risk female readers. It came up with "You," a weekly section for women. Some 240 women were interviewed about the section and 6 out of 10 of the at-risk readers preferred "You" to the paper's current "Lifestyle Section." All readers liked that the section was explicitly for women. The at-risk readers particularly liked colorful graphics, short bullets of information, and the "Parents and Children" portion.

The American Society of Newspaper Editors (1991) also asked the Wisconsin State Journal to come up with a prototype of a "Lifestyle Section" for potential and at- 
risk readers. A typical at-risk or potential reader is a man or woman under 30 who has recently experienced a major life change (marriage, divorce, child, new job). The society-sponsored survey of 1,264 adults in the contiguous United States found that these groups of readers both want coverage of children, of families, and of childrearing. So, the Wisconsin State Journal developed "Rumpus," a section that was segmented for different age groups of children and for parents. The newspaper found that $41 \%$ of at-risk readers and $30 \%$ of potential readers felt the newspaper with the "Rumpus" section would be more appealing to them. But the survey also found that "Rumpus" should be an addition to the paper, not a replacement for the existing, broadly focused "Lifestyle Section."

\section{Criticism and Analysis of "Lifestyle Sections"}

Much of what was written after the 1970s about changes in "Lifestyle Sections" appeared as criticism and analysis - not research - in magazines, newspapers, and books. D'Arcy (1984) noted that although food was still covered in the "Lifestyle Sections," the coverage was apt to be about nutrition, research, cost, and quality; although fashion was still covered, it was more likely to tell readers how to gain an expensive look at low cost than relaying edicts from New York; although there was still society coverage, it was more apt to do with how the rich live than who attended what party; wedding coverage was shorter and less apt to be based on socio-economic status in the community; club news was reported only when a club actually accomplished something; and home decor was more consumer oriented.

Some of the "Lifestyle Sections" were tying their coverage directly to news reports. Newsday's Part III won the Penney-Missouri award for best "Lifestyle Section" four out of six years by keeping its stories focused on news, according to Editor and 
Publisher (1980). Finney (1983), Horgan (1983), Kampinsky (1984), and Miller (1990) all noted a trend in the 1980s of segmenting the "Lifestyle Sections." Instead of appealing to a broad audience as originally initiated, the sections were geared to attracting target audiences. "The new thinking was to use the features section to appeal to target audiences of various ages, by focusing on topics of special appeal to these groups. Many papers adopted daily theme pages with this strategy in mind," Miller stated (p. 4). Laventhol (1984) predicted that "Lifestyle Sections" would stabilize as a regular part of the newspaper, but that periodic or annual special sections or targeted pages geared toward specialized interests would become popular.

Other writers claimed that the changes in "Lifestyle Sections" had gone too fai. Houck (1984) stated that American newspapers, guilty over being male oriented, changed their "Women's Pages" and in the process, "killed off the only section in their paper that was designed to appeal to women" (p. 16). D'Arcy (1984) said what started out as a movement to capture the disappearing modern woman reader may have backfired on itself. Mills (1988) stated that Jean Taylor, editor of "View," the Los Angeles Times' "Lifestyle Section," worried that such sections may have gone too far in attempting to understand society and have lost their unique women's perspective. Meyers (1990) quoted Woodhull as saying that newspapers may have made a mistake in dropping women's sections because women's magazines have taken over that area of coverage.

A trend back to "Women's Pages" was documented in newspapers, magazines, and books in the 1980s. Editor and Publisher (1980) reported that King Features Syndicate had introduced a syndicated section, "Sunday Woman," in 1980 . The section folded in 1987, according to its former editor Merry Clark (personal communication, March 28, 1991), but not because it was not popular. The section, she 
said, had doubled in circulation since 1982 , reaching 70 daily newspapers with a total circulation of 4 million. (Daily newspapers today reach approximately 62.6 million readers in the U.S.) A 1982 study by the Sacramento Bee (Astor, 1989) showed that $98 \%$ of female readers read the section, $50 \%$ of male readers read it, and $54 \%$ of all readers preferred it to other sections. Clark blamed the weakening economy on the folding of the section. It was a Sunday magazine in which local newspapers could insert their own copy. But this proved to be an expensive process, and when newspapers began cutting back, "Sunday Woman" was eliminated by many newspapers, Clark said.

Other writers also wrote about the move back to "Women's Pages." Jim Daubel of the Fremont (OH) News-Messenger (cited in Archbold, 1982) stated that the paper swung away from club and social news, but after a violent reaction from readers, brought some of it back. After that, Daubel stated, the sections evolved by the late 1970s to include more men's issues, youth issues, advice columns and home features. Rykken (1988) noted that after years of neglect, items from the traditional women's pages were finding their way back into newspapers as editors increasingly took readers' interests into consideration in deciding on content. Rykken (1988) noted that papers are returning to scciety news and are printing wedding announcements free of cost after some papers dropped these announcements and others started to charge for them. But Mills (1988) warned lifestyle editors to guard against their sections becoming "a ghetto of women's news" when female editors on news side cannot muster up enough interest for stories pertaining to women.

"Lifestyle Sections" of the 1980s faced an identity crisis. Bob Haiman, executive editor of the St. Petersburg (FL) Times (cited in Archbold, 1982) said that most of the sections were still struggling through their evolution. Janet Sanford, editor 
of USA Today who studied "Lifestyle Sections" for four years (cited in Horgan, 1983), said:

I have a sense that right now, many sections have lost their identity. They don't know quite what they want to do. A lot of it is due to their early success. Now the news sections have become more people-oriented, lifestyle sections have found that part of their special attraction has been taken away from them. (p. 22)

The question of where these sections are going has been addressed in several articles. According to Scott (1987), they are changing from sections with articles on coping with life to sections with articles on how to improve the quality of life. McGehee (1988) suggested that the sections regain focus and do some fundamental rethinking. Mills (1988) said that newspapers must have a clearer definition of what is to be covered in their "Feature Sections" and a firm commitment to cover a broader range of news throughout the newspaper.

This very issue of where these sections should be headed was addressed during two sessions of the Newspaper Features Council (Astor, 1989). Judy Markey, humor columnist with the Chicago Sun-Times and North American Syndicate, said that "Features/Entertainment Sections" should be aimed at time-strapped, modern women. Markey said the sections should include articles on menu planning, new videos, affordable clothes, day care, and single parenting. She added that there also should be humor. Jane Amari, managing editor-features at the Los Angeles Daily News, said features editors should run irreverent and silly things from time to time, and shorter stories to attract younger readers. Joe Bob Briggs, author of satirical columns about modern life, called for hip comedy material and more music coverage to attract 
younger readers. Several panelists also noted that the comics page was an important element of the section.

Miller (1990) still shows interest in these sections. She suggests that they go after baby-boomer households, especially baby-boomer women (those born between 1946 and 1964), because this is the biggest untapped market share available to newspapers. The sections should stop trying to segment themselves to appeal to different populations, but instead have a coherent focus, organization, and tone, according to Miller. She stated:

In general, the goal of the features section should be to offer practical advice on housekeeping, child-rearing, balancing multiple roles, reducing stress, personal relationships, health, eating (eat-it-out, bring-it-home, quick fix, and other foods most people eat), time-saving, shopping, new products and services, and other consumer-oriented topics. Essentially, features should specialize in topics related to how people use their non-work hours - especially stories that can help people handle the mandatory so they have more time for the discretionary. These should be presented with tightly focused writing, multiple points of entry, briefs, lists of tips, clip and save, hot button headlines, and anything else that says clip me. There should be absolutely predictable organization and scheduling (features in the same place every day or every week). (p. 6) Miller added that this does not mean a return to "the women's section ghetto of the 1960s" (p. 7). Instead, she said that the sections should focus on a group of related topics, not on gender per se. And it is these topics, not gender, that should define the section, according to Miller.

The prototypes commissioned by the American Society of Newspaper Editors in both 1990 and 1991, however, are exactly what Miller is talking against - weekly 
sections focused at a specific group of readers. So, it appears there is disagreement within the industry over whether these sections should be segmented to appeal on each given day to a different segment of the population, or should consist of a group of related topics offered to the reader on a daily basis. 


\section{CHAPTER III}

\section{METHODOLOGY}

A content analysis looked at a four-week sample of The New York Times, Washington Post, Chicago Tribune, and Los Angeles Times in 1989. The content analysis was organized to approximate the study done by Miller (1976) of the "Women's Päges" and "Lifestyle Sections" of these papers in 1965 and 1975. The weeks studied were Jan. 1-7, 1989, April 2-8, 1989, July 2-8, 1989, and Oct. 8-14, 1989. Miller originally chose the corresponding weeks in 1965 and 1975 to avoid proximity to holidays or other events that might skew coverage. The content analysis examined articles, advertisements, and photographs in these sections, using most of the methodology developed by Miller (1976).

Like Miller's, this analysis did not take into account either the length or tone of individual articles. As Miller (1976) stated, even though stories, photos, and ads may differ in length, each represents a single editorial judgment as to inclusion or exclusion. The presence or absence of an article, photo, or ad is more important than length in measuring the number and variety of topics. Furthermore, style or tone are not considerations if coverage is lacking, Miller (1976) noted.

The 1989 content analysis examined a few areas of content not studied by Miller. Articles dealing with saving time and articles dealing with sex roles were included in 1989, but were not separately tallied in 1965 and 1975. They were included because Miller (1990) believes they should be addressed in these sections.

Graphics were not counted in 1965 and 1975, but were included in 1989 because the use of graphics has gained in popularity in recent years as newspapers attempt to entice younger readers who have been raised on the visual world of television. Also, "at-risk" readers, those who read the newspaper two to four times a 
week but are dissatisfied with the paper, mentioned they liked colorful graphics included in a prototype "Women's Section" developed by the Lexington Herald-Leader (American Society of Newspaper Editors, 1991). At-risk readers tend to be under age 30 , again showing the desire of youth for graphics.

Entertainment pages elsewhere in the newspaper were not counted in 1989 as they were in 1965 and 1975. Miller (1976) noted that the number of "Lifestyle" pages in all but The New York Times had decreased in size between 1965 and 1975, while all four papers had increased their "Entertainment Sections." But Miller did not look at what was happening in any of the other sections of the newspaper. If this study were to show that "Features/Entertainment Sections" had continued to decrease in size since 1975, all sections of the paper would have to be studied to determine where growth was occurring. This was not done as part of this study.

\section{Operational Definitions}

Operational definitions are identical to Miller's, except for additional definitions for articles dealing with time saving and articles dealing with sex roles, which were not included in the Miller's 1976 study. Lifestyle and/or consumer coverage was defined as stories presenting information relevant to the lives of average citizens, and focusing on the opinions and activities of local people. That is why there is a separate category for syndicated features, even though some cit these might present "lifestyle" or "consumer" information. The operational definitions are as follows:

Lifestyle articles: articles involving personal relationships, work and work relationships, child rearing.

Consumer articles: articles involving health, home care and furnishings, finances and purchases, and environmental issues. 
Social articles: articles involving social events, weddings, engagements, and anniversaries.

Entertainment articles: articles involving entertainment and the arts, and hobbies.

Syndicated articles: articles that are from syndicated sources and involve personal advice, child rearing, health, consumer, hobbies, and fashion.

Politics/Other: all other articles that do not fit into the above categories, including articles on sex roles and time saving.

In addition, the following guidelines were designed for separate story categories:

Stories about personal relationships deal with the private relationship between two or more people. They can deal with such things as living together, divorce, marriage.

Articles about work and work relationships deal with situations on the job. The gist of the story is what the person does for a living or relationships with others on the job.

Articles about child rearing deal with ways of raising children, problems parents face in raising children, and the education of children.

Articles about time saving deal with how to save time in this busy lifestyle we lead today. For example, a story on how to quickly organize a dinner party or an article on the fastest route to work would be considered articles about time saving. Articles on sex roles deal with men and women and how their roles are changing in society. For example, an article dealing with the rise in the number of female executives or an article about men who stay home to raise children would enter into this category. 
Health articles deal with a disease, medicine, dieting, or other types of physical or mental health issues. Articles on abortion or AIDS most likely would fit in this category if they are related more to health than to politics or personal relationships.

Articles on home care and furnishings deal with interior decorating, painting, roofing, or articles for the home.

Articles on finances and purchases deal with such things as financial advice, economics, best buys, and where to buy things.

Articles on environmental issues deal with such things as air pollution, chemicals in food, the ozone layer, and recycling.

Food articles deal mainly with recipes. They include articles on nutrition.

Fashion articles are mainly style stories. They deal with what is in style, what designers are coming up with, hair, cosmetics, and clothing.

Social events are gatherings that are for charity, such as a charitable ball or even an announcement of a speaker at a charitable event. These articles include parties, announcement of club meetings, and leisure activities that are social in nature.

Articles on engagements and weddings are announcements of these events. Anniversary announcements are included in this category.

Articles on entertainment and the arts include reviews (including book reviews), news about shows and productions, and profiles on entertainers.

Articles on hobbies deal with any hobby such as gardening or collecting. Syndicated articles and columns are not written by a staff member of the newspaper. Columns often are syndicated. If there is an explanation of who the author is at the end of an article, this often indicates that it is syndicated. Articles from the Associated Press or United Press Internationals are syndicated. Astrology and bridge columns usually are syndicated. Astrology columns are included in the personal 
advice/syndicated category. Columns on bridge are included in the hobbies/syndicated category.

All pages were counted, including pages that contained all advertisements or all comics. TV and radio listings, comics appearing alone on a page, and crossword puzzles were counted as graphics. Graphics were considered any art, chart, or graph that was not a photograph.

For units of observation, see Table 3.

All four newspapers were contacted to ascertain what constituted the "Lifestyle Section" or "Feature Section." Included in the content analysis were the "Style" and "Style Plus" sections of the Washington Post, the "View" section of the metro edition of Los Angeles Times; the "Tempo," "Tempo Woman," and "Tempo Arts" sections of the Chicago Tribune, and the following sections in the final late editions of The New York Times: "Living Arts," "Life Style," "Evening Hours," "Weddings," "The Arts/News and Reviews," "Pastimes," "The Living Section," "The Home Section," "Fashion," and "Consumer's World."

\section{Intercoder Reliability}

Two coders besides the author were used in the content analysis. To insure coder reliability, a pretest was given. Both coders were asked to count the numbers of articles, ads, and photographs in the various categories from the July 18, 1989 "View" section of the Los Angeles Times. Intercoder reliability was found with an inter-rater reliability coefficient of $84.4 \%$. To ensure intercoder reliability, an inter-rater reliability coefficient of at least 80 percent was desired.

Each coder was randomly assigned certain weeks of newspapers to code. The author coded The New York Times for the weeks of Jan. 1-7, 1989, April 2-8, 1989, and Oct. 8-14, 1989; Chicago Tribune for the weeks of Jan. 1-7, 1989 and Oct. 8-14, 
Table 3

\begin{tabular}{|c|c|}
\hline \multicolumn{2}{|c|}{ Units of Observation } \\
\hline Total photos & Ads for women \\
\hline Photos of women & Ads for men \\
\hline Photos of men & Ads for men and women \\
\hline Photos of men and women & Total ads \\
\hline Stories about: & Stories on politics/other subjects \\
\hline Personal relationships & Stories on time saving \\
\hline Work and work relationships & Stories on sex roles \\
\hline Child rearing & Syndicated: \\
\hline Total lifestyle stories & Consumer stories \\
\hline Stories about: & Hobby stories \\
\hline Weddings and engagements & Personal advice columns \\
\hline Social events & Child rearing stories \\
\hline Total social stories & Fashion stories \\
\hline Stories about: & Health stories \\
\hline Finances and purchases & Other topics \\
\hline Environmental issues & Total syndicated stories \\
\hline Health & Total pages \\
\hline Home care and furnishings & Total graphics \\
\hline Total consumer stories & Food stories \\
\hline Stories on: & Fashion stories \\
\hline Hobbies & Total stories \\
\hline Entertainment and arts & Total entertainment stories \\
\hline
\end{tabular}


1989; Washington Post for the week of April 2-8, 1989; and the Los Angeles Times for the week of July 2-8, 1989. One coded the Washington Post for the weeks of Jan. 1-7, 1989 and Oct. 8-14, 1989; the Los Angeles Times for the weeks of April 2-8, 1989 and Oct. 8-14, 1989; The New York Times for the week of July 2-8, 1989; and the Chicago Tribune for the weeks of April 2-8, 1989 and July 2-8, 1989. The other coded the Washington Post for the week of July 2-8, 1989 and the Los Angeles Times for the week of Jan. 1-7, 1989.

\section{Statistics Used}

Chi square was the appropriate statistic for this content analysis. Chi square was used to determine if there were significant differences across time and across newspapers in: total articles, lifestyle articles, consumer articles, food articles, fashion articles, social articles, entertainment articles, syndicated articles, articles on politics and other subjects, articles about women, articles about men, articles about both men and women, photos of women, photos of men, photos of both men and women, total photos, ads for women, ads for men, ads for both men and women, and total ads.

Chi square also was used to determine if there were significant differences across time and across newspapers in the various story categories: personal relationships; work and work relationships; child rearing; health; home care and furnishings; finances and purchases; environmental issues; social events; engagements and weddings; entertainment and arts; hobbies; and syndicated articles on personal advice, health, consumer issues, hobbies, fashion, and other topics. Chi square also was used to determine if there was a significant difference in the distribution of types of articles, photos, and ads across time in each individual newspaper. The same 
categories were analyzed as were analyzed in looking at the differences in all newspapers over time.

\section{Qualitative Data}

As part of the study, qualitative data were gathered through interviews with six "Feature Section" editors from newspapers throughout the United States. Four of the newspapers were selected because they recently have taken innovative steps with their "Feature Sections." One was chosen because it was part of the study.

Gilbert Watson, "Feature Section" editor for the Baltimore Sun and president of the American Association of Sunday and Feature Editors, recommended the Orange County (CA) Register because of its innovative "Newspaper Without Walls" program in which reporters are not assigned via the traditional "beat" system and editors are not put in charge of specific sections. Instead, reporters and editors work in topic areas. Watson also recommended the Boca Raton (FL) News because of its "25-43 Project" to entice the baby-boom generation.

Susan Miller, vice president/editorial for Scripps Howard Newspapers, suggested the Commercial Appeal of Memphis, TN because a recent readership survey showed this paper's readership by women had increased dramatically. Karen Wada, the new "Feature Section" editor for the Los Angeles Times, noted that because of her short time with the "View" section, it would be best to speak with former editor Jean Sharley Taylor. The author of this study selected the Santa Cruz (CA) Sentinel because as an employee there, she was aware that the "Feature Section" in 1991 changed from a "Lifestyle Section" to a "Feature/Entertainment Section" through the combination of the lifestyle and entertainment departments. 
Editors interviewed were Jackie Kerwin of the Boca Raton News, John Holland of the Orange County Register, Roslyn White of the Commercial Appeal, Marybeth Varcados of the Santa Cruz Sentinel, Wada of the Los Angeles Times, and Taylor, formerly with the Los Angeles Times.

All editors were interviewed by telephone except for Varcados, who was interviewed in person. The questions they were asked were:

Why did these sections decrease in size between 1965 and 1975 and then increase in size between 1975 and 1989 ?

Are newspaper publishers putting a greater emphasis on these sections? If so, why?

Are these sections increasing in size because they are being combined with other sections, such as entertainment?

Is your section publishing more entertainment articles than in the past?

Is your section publishing more syndicated articles than in the past?

Is your section publishing a greater variety of articles than in the past? If so, what type?

Has your section decreased its coverage in any of the following areas: lifestyle articles in general, lifestyle articles concerning personal relationships, articles on finances and purchases, fashion, or social events? If so, why?

Has your section purposely moved away from aiming itself at women readers since 1965? If so, why?

What specific audience does your section plan to target in the next few years?

Do you see any need to change your section to attract women readers? 


\section{CHAPTER IV}

\section{RESULTS}

Significant differences were found using chi square in all categories tested in which there was enough data. There was insufficient data (too many cells with expected frequency of 5 or less) in some cases. In a few instances, the cells with too little data were removed and chi square test performed without that data.

Data not included in Miller's (1976) study could not be analyzed over time using chi square. These data included: graphics, stories on time saving, and stories on sex roles. This data was analyzed by the author making observations about what was included in 1989 newspapers.

Because of the large number of significant differences found over time across newspapers and the large number of significant differences found over time in individual newspapers, chi square computational tables and results are included in Appendix A.

"Feature Sections" Increase in Size

The "Feature Sections" in these newspaper increased in size over the 14 years studied. There was a significant difference in the total number of articles printed over time across all four newspapers (Appendix A). The number of articles decreased at all four newspapers between 1965 and 1975, but increased between 1975 and 1989 (Table 4). The number of articles in 1989 was larger than the number of articles in 1965 at all papers except the Los Angeles Times. Additionally, the average number of pages increased at all four newspapers in 1989 over both 1965 and 1975 (Table 5). Between 1965 and 1975, the average number of pages decreased at all but The New York Times, which increased by an average of one page a week. Chi square cannot be used to 


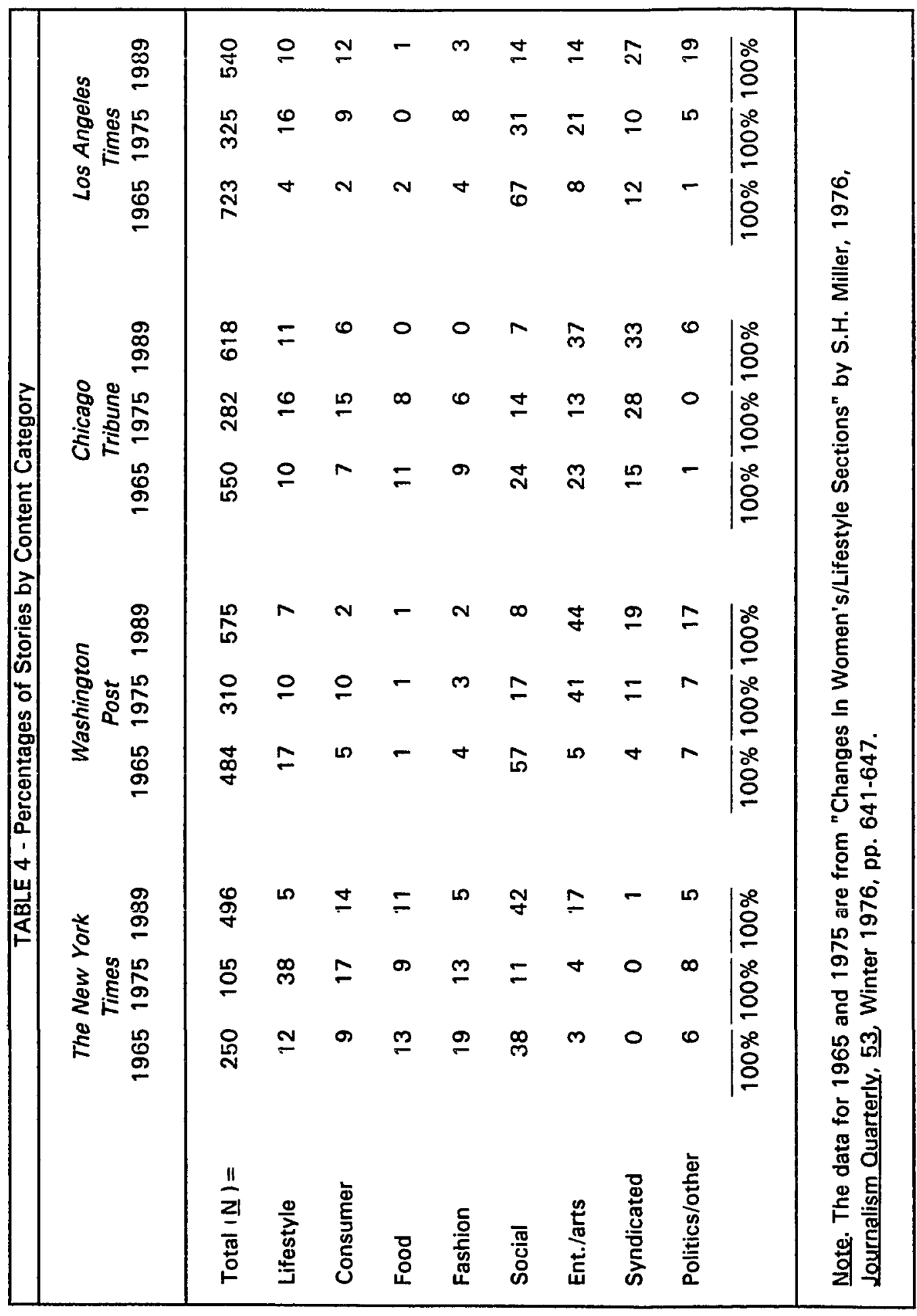


determine significant differences among averages, so these are noted, but not staistically analyzed.

\section{Table 5}

Average Number of Lifestyle Pages Per Week

\begin{tabular}{|rccc|} 
& 1965 & 1975 & $\underline{1989}$ \\
\cline { 2 - 4 } The New York Times & 9 & 10 & 44 \\
Washington Post & 52 & 47 & 83 \\
Chicago Tribune & 41 & 34 & 43 \\
Los Angeles Times & 66 & 34 & 73 \\
\hline
\end{tabular}

Note. The data for 1965 and 1975 are from "Changes in Women's/Lifestyle Sections" by S. H. Miller, 1976, Journalism Quarterly, 53, Winter 1976, p. 643.

Readers were getting more articles and larger sections in 1989 than they did in 1975, but the average number of stories (Table 6), photos (Table 7), and ads (Table 8) per page stayed largely the same. The same was true between 1965 and 1975, with the exception of The New York Times, which decreased from an average of seven stories per page in 1965 to three in 1975.

Chi square also was used to analyze what was occurring with the number of articles at individual newspapers. Each of the four newspapers showed a significant difference in the number of articles over time (Appendix A).

There are three main reasons for the increase in size of these sections, according to interviews with six "Feature/Entertainment Section" editors. Newspaper management was taking a greater interest in these sections, a healthy economy in the 
1980 s brought more advertisements into these sections, and sections were offering a greater variety of articles. All six editors said their sections had increased since the mid-1970s.

\section{Table 6}

Average Number of Stories Per Page

\begin{tabular}{|rccc|}
\hline & 1965 & $\underline{1975}$ & 1989 \\
The New York Times & 7 & 3 & 3 \\
Washington Post & 2 & 2 & 2 \\
Chicago Tribune & 3 & 2 & 4 \\
Los Angeles Times & 1 & 1 & 1 \\
\hline
\end{tabular}

Note. The data for 1965 and 1975 are from "Changes in Women's/Lifestyle Sections" by S. H. Miller, 1976, Journalism Quarterly, 53, Winter 1976, p. 643.

Newspaper managements' interest in increasing the size of the section was apparent by the early 1980 s. A survey by the Associated Press Managing Editors Modern Living Committee (1981) of section editors found that most said their news hole had increased. A majority also said their newspapers had a greater commitment toward the section. Taylor - women's editor at the Los Angeles Times from 19711973, "View" editor from 1973-1975, and associate editor overseeing the section from 1975-1989 - said the paper's commitment to the section was evident in the early 1980s (personal communication, May 20, 1991). When the daily "Calendar" section was split off from "View," Taylor said she received a commitment from management that 
"View" would not get any smaller than eight pages and that the comics section would be added to anchor the section.

\section{Table 7}

Average Number of Photos Per Page

\begin{tabular}{|rccc|}
\hline & 1965 & 1975 & 1989 \\
\cline { 2 - 3 } The New York Times & 3 & 2 & 1 \\
Washington Post & 1 & 1 & 1 \\
Chicago Tribune & 2 & 2 & 3 \\
Los Angeles Times & 1 & 1 & 1 \\
\hline
\end{tabular}

Note. The data for 1965 and 1975 are from "Changes In Women's/Lifestyle Sections" by S. H. Miller, 1976, Journalism Quarterly, 53, Winter 1976, p. 643.

\section{Table 8}

Average Number of Ads Per Page

\begin{tabular}{|rccc|}
\hline & 1965 & 1975 & 1989 \\
The New York Times & 5 & 3 & 3 \\
Washington Post & 4 & 3 & 3 \\
Chicago Tribune & 2 & 3 & 4 \\
Los Angeles Times & 2 & 4 & 3 \\
\hline
\end{tabular}

Note. The data for 1965 and 1975 are from "Changes In Women's/Lifestyle Sections" by S. H. Miller, 1976, Journalism Quarterly, 53, Winter 1976, p. 643. 
An interest in capturing the lucrative baby-boomer market, those readers born between 1946 and 1964, is one reason newspapers are putting more emphasis on these sections. This is evident at the Boca Raton News, the 30,000 circulation paper in Florida selected by the Knight-Ridder chain in October 1990 for a complete make-over to attract readers from ages 25 to 43 . The "Feature Section," noted editor Kerwin (personal communication, May 17, 1991), has doubled in size under the so-called "2543 project." The biggest change at the paper overall is that stories no longer jump, but the second biggest change has been in the "Features Section," called "Essentials," Kerwin said. Management felt "Essentials" was the section that could best reflect the needs of baby boomers, she said. But even before the project started, "Essentials" had been growing for over five years. She said:

The growth has been generally in response to readers' needs and desires. Ten to 15 years ago, these sections were considered Women's Sections and interest in them fell off as women entered the work force. The sections were then redefined to give news for men and families, and they grew in size (personal communication, May 17, 1991).

Growth in the U.S. economy from the mid-1970s to the late 1980s brought more advertisement to these sections, thus increasing their size. Department store ads were integral to the expansion of the "View" section at the Los Angeles Times, according to former editor Taylor (personal communication, May 20, 1991). During this time, Robinson's department store agreed to run ads in the first few pages of the section as long as the newspaper agreed to include society coverage on pages three and four, she said. In the 1980s, Bullock's department store began advertising toward the back of the section and agreed not to advertise in any other paper in the Los Angeles Times' subscription area, she added. 
"Features/Entertainment Sections," however, began to decrease in size in the 1990s because of the recession. Wada, named editor of the "View" section at the Los Angeles Times in December 1990, said the section has decreased in size since 1989 (personal communication, May 17, 1991). The large department stores have all changed ownership in recent years and are not represented in the section as they once were, according to former editor Taylor (personal communication, May 20, 1991). "If you look at today's section, they have a six-page minimum and not that many ads," she said. "Almost more than any other section, the features sections are dependent on department store advertising." The competing Orange County Register also has reduced its section because of the recession, according to assistant managing editor Holland (personal communication, May 17, 1991). "But in general, from 1975 on, we have grown as well," said Holland, whose paper recently began operating as a "newspaper without walls" where reporters are not assigned to any specific section or beat. "Features/Entertainment Section" articles come from reporters working in many areas of the Southern California paper with a weekday circulation of 372,000 .

The trend toward offering more variety in these sections also added to their size. The fact that all four newspapers that were studied increased in the number of "politics and other" types of articles (Table 4) shows that these papers are offering the type of stories that traditionally have not appeared in "Features/Entertainment Sections." Other papers are offering more variety "because there is more information out there. There are more syndicated columnists, more comics, more things to choose from," said White, editor of the "Appeal" section of the Commercial Appeal, the Memphis, Tenn. paper with a weekday circulation of 197,000 .

Some newspapers, like The New York Times, have segmented their "Features/Entertainment section" into theme sections each day. This has occurred also 
at the Boca Raton News. The variety is evident in what is offered each day as the "Essentials" section - a traditional "Features Section" on Sunday, business on Monday, health and fitness on Tuesday, parent and child on Wednesday, "the good life" on Thursday, entertainment on Friday, and home and garden on Saturday. The Orange County Register's "Accent" section also has theme sections five out of seven days a week.

"Features/Entertainment Section" editors have also tried to attract a wider audience by broadening their coverage, which has increased the amount and variety of articles. The Los Angeles Times' "View" section grew as the it attempted to bring in male readers, according to former editor Taylor (personal communication, May 20 , 1991). In attempting to reach more readers in the 1970s, the section concentrated on the type of coverage not done in the main sections. "We were able to do the psychological reasons for things, why people do what they do, the communality that touches us all," she said. Holland of the Orange County Register said the section there grew because its staff got more ambitious. He said:

There were many more things we wanted to do. We viewed our roles as much more expanded. We were not only doing the traditional feature stories, but also stories on giving readers tips and helping them make sense out of their lives (personal communication, May 17, 1991).

Some sections grew as they merged with other sections. "Features" at the Santa Cruz Sentinel, for example, has grown since the early 1980s as it absorbed former separate food, home and garden, and health and science sections. In the Fall of 1991, it also absorbed the once separate "Entertainment Section," becoming a "Features/Entertainment Section." Editor Varcados, who oversees the "Features/Entertainment Section" in this Northern California paper with a weekday 
circulation of 28,500 , said the mergers gave the paper a more standardized look (personal communication, May 14, 1991). Instead of having several editors putting out several separate sections all with their own look, she explained, there now is only one editor putting out a section that looks like other sections of the paper. Also, the paper is moving into pagination, and fewer separate sections mean fewer editors to train, she noted.

\section{Changes In Types of Articles}

When looking at all four newspapers over time, significant differences were found in the number of total lifestyle, consumer, food, fashion, social, syndicated and entertainment articles; and articles about personal relationships, work and work relationships, child rearing, health, finances and purchases, social events, weddings and engagements, entertainment and the arts, and politics and other subjects not usually found in "Features/Entertainment Sections" (Appendix A).

The percentage of lifestyle articles decreased at all four newspaper between 1975 and 1989 (Table 4), but the actual number went down only at The New York Times. Between 1965 and 1975, the record was mixed. The New York and Los Angeles papers had increased both the percentage and number of lifestyle stories. The Chicago paper, while increasing its percentage, reduced the number. The Washington paper had decreased both the percentage (Table 4) and the number.

Looking at individual newspapers over time, there was a significant difference in the number of lifestyle articles at all four papers (Appendix A).

Chi square also was used to analyze the various lifestyle story categories: personal relationships, work and work relationships, and child rearing. All four newspapers experienced an increase in the percentage of articles about personal 
relationships between 1965 and 1975 (Table 9). But between 1975 and 1989, the percentage and number at all the newspapers decreased (Table 9).

At all papers but The New York Times, the percentage of articles about work and work relationships decreased between 1965 and 1975 and then increased between 1975 and 1989 (Table 9). In the New York paper, the percentage and number increased between 1965 and 1975 and then decreased. The number of articles in the Chicago Tribune and in the Los Angeles Times continued to increase over the years, while the number at the Washington Post went down between 1965 and 1975 and then up again.

At all papers but the Washington Post, the percentage of articles about child rearing increased between 1965 and 1975 and then decreased between 1975 and 1989 (Table 9). At the Washington Post, the percentage decreased between 1965 and 1975 and then stayed the same in 1989. All the papers except for the Washington Post had fewer of these stories in 1989 than they did in 1965 or 1975. The Washington Post had slightly more in 1989 than in 1975, but both years were much lower than 1965.

As for consumer articles, after the percentage of articles increased at all four newspapers between 1965 and 1975, it decreased at all but the Los Angeles Times between 1975 and 1989 (Table 4). The number of articles continued to decrease over the years after 1965 at all newspapers except for The New York Times, where the number increased between 1975 and 1989.

There was only enough data to analyze the differences in consumer articles over time in one individual newspaper, the Chicago Tribune. There was a significant difference in the number of consumer articles over time in this paper (Appendix A). 


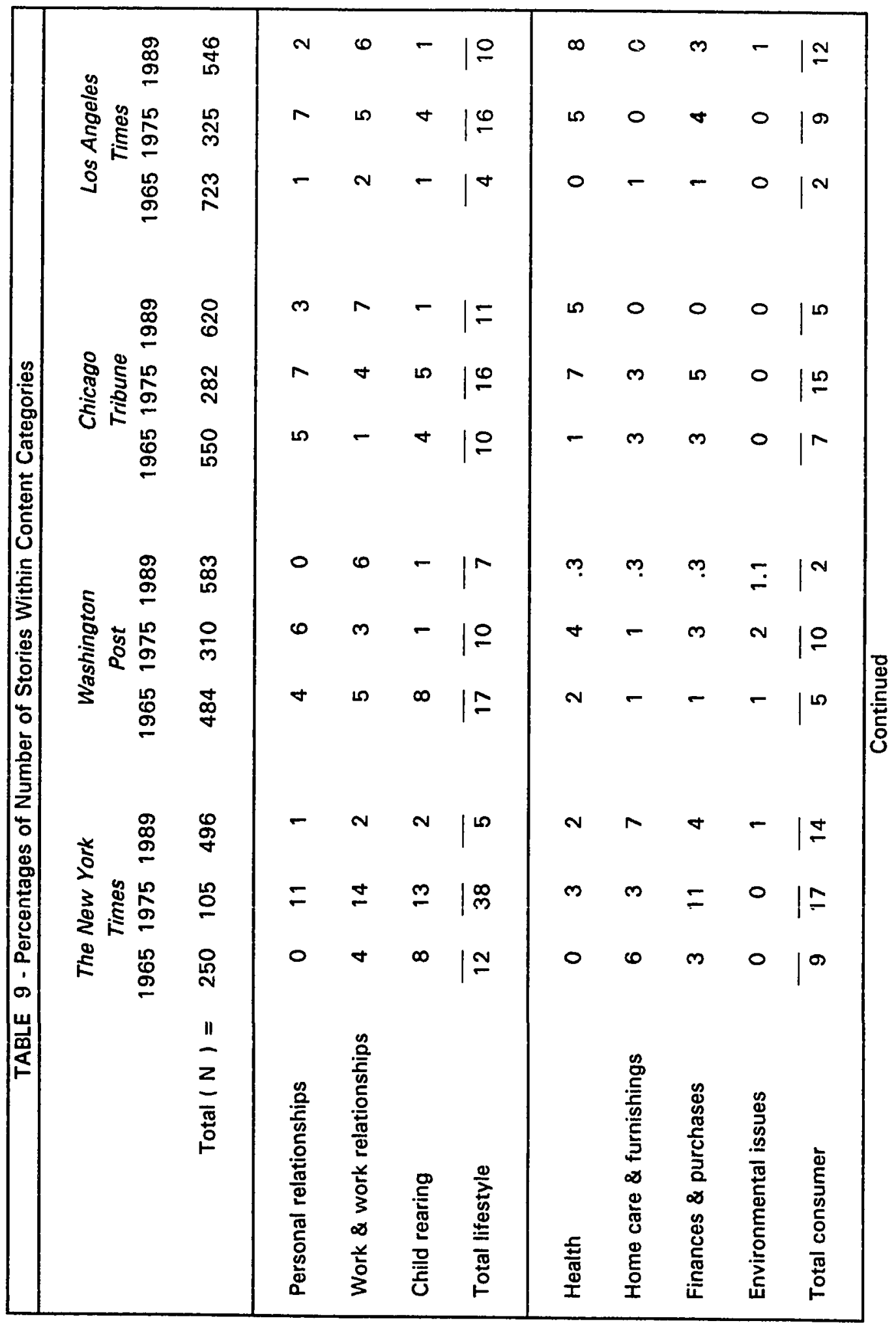




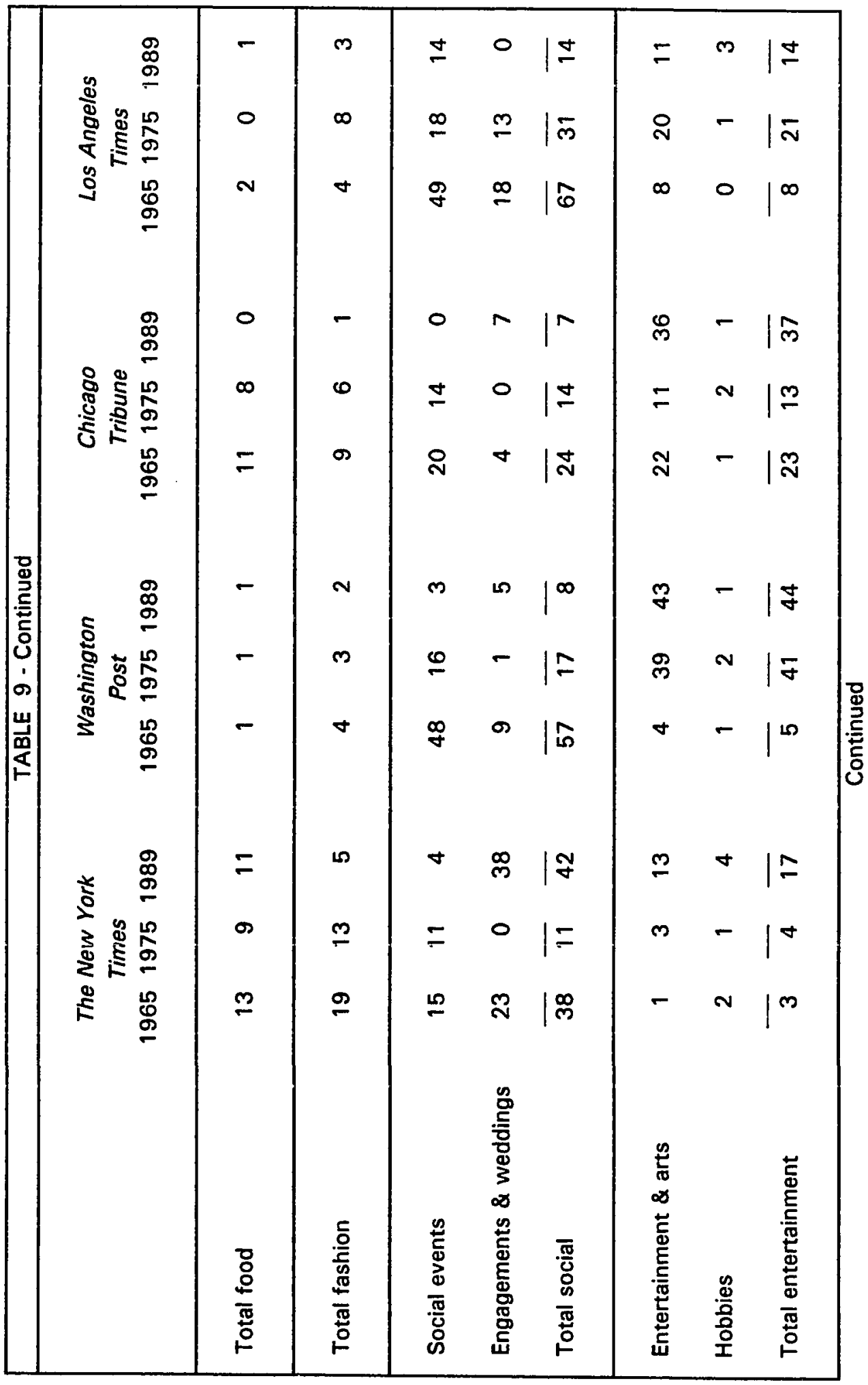




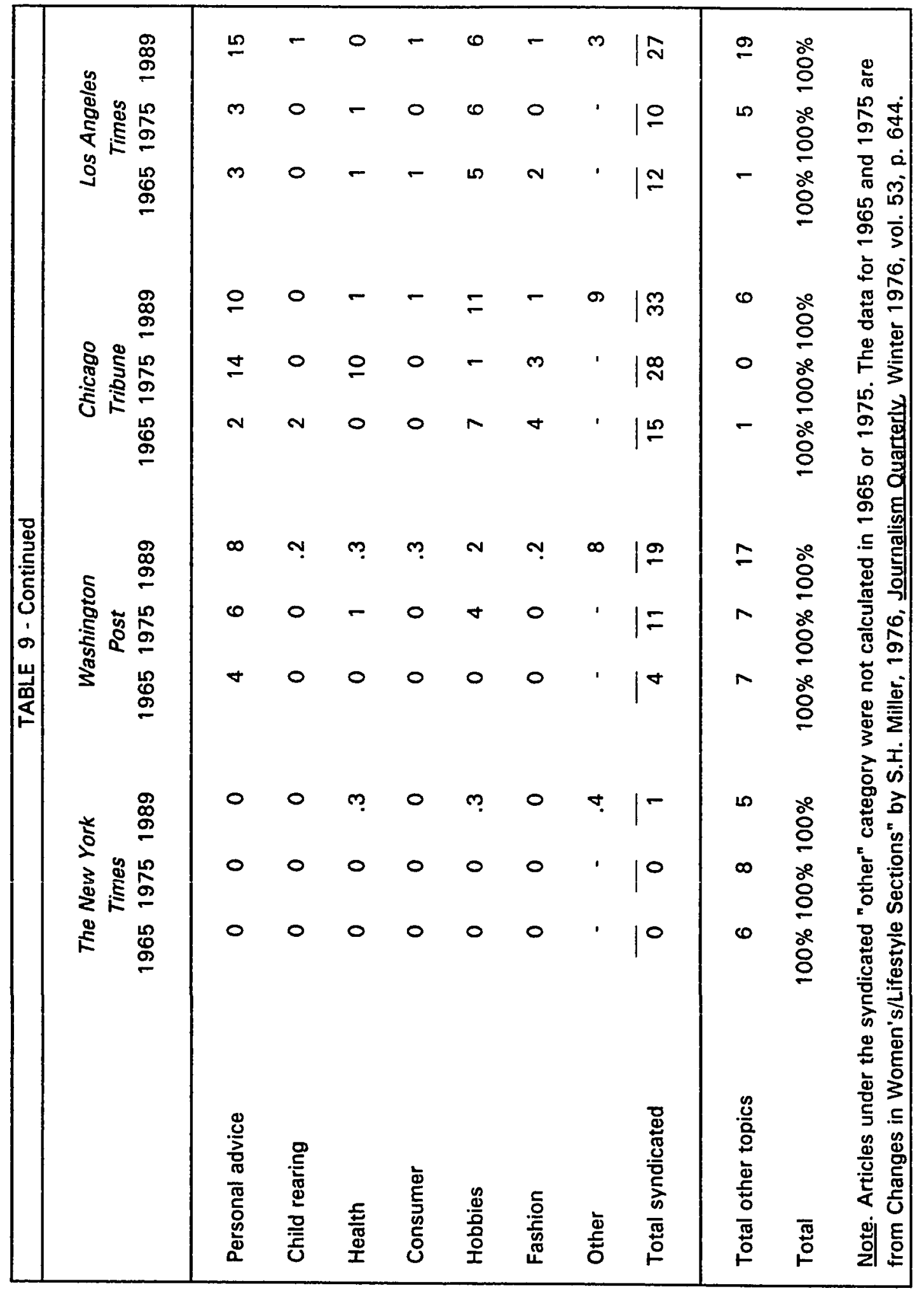


Chi square also was used to analyze the various story categories of consumer articles: health, home care and furnishings, finances and purchases, and environmental issues. After the percentage of health articles increased in all newspapers between 1965 and 1975, it decreased at all but the Los Angeles Times between 1975 and 1989 (Table 9). The numbers of articles, however, continued to increase over the years at all but the Washington Post, where the numbers fell between 1975 and 1989.

At all newspapers, the percentage of articles about finances and purchases increased between 1965 and 1975 and then decreased between 1975 and 1989 (Table 9). But the numbers tell a slightly different story. The number of articles increased over the years at The New York Times and the Los Angeles Times, went up and then down at the Washington Post, and continued to decrease at the Chicago Tribune.

There was not enough data to analyze articles about environmental issues and articles about home care and furnishings over time across newspapers. These type of articles made up a very low percentage of total articles at all papers over time with the exception of home care and furnishing articles at The New York Times (Table 9).

The percentage of food articles either decreased or stayed the same between 1965 and 1975. There was a change between 1975 and 1989, with the percentage increasing slightly at The New York Times and the Los Angeles Times (Table 4). It went down at the Chicago paper and stayed the same at the Washington paper. The number of articles went down at all four papers between 1965 and 1975 and continued to decrease at all but The New York Times between 1975 and 1989.

The percentage of fashion articles at all four papers in 1989 was lower than it was in 1965 and in 1975 (Table 4). Only the Los Angeles Times showed a slight increase in the percentage of these articles between 1965 and 1975 before falling again. The number of articles has continued to decrease since 1965 at both the Chicago 
Tribune and Los Angeles Times. It has gone down and then back up again at the other two papers, but never reached the point it was at in 1965 .

The percentage of social articles continued to decline after 1965 at all newspapers except The New York Times, where the percentage and number declined between 1965 and 1975, and then increased in 1989 to a point higher than 1965 (Table 4). The number has continued to decline over the years at the Washington Post and Los Angeles Times, while it went up slightly at the Chicago Tribune between 1975 and 1989. Looking at individual newspapers over time, all four papers show a significant difference in the number of social articles.

Analysis was also done of the two story categories that make up social articles social events and weddings and engagements. The percentage of articles on social events continued to decrease at all four newspapers from 1965 to 1975 to 1989 (Table 9). The number of articles, however, actually went up between 1975 and 1989 at The New York Times and the Los Angeles Times. The percentage and number of wedding and engagement announcements decreased at all four newspapers between 1965 and 1975. The percentage and number then went up again between 1975 and 1989 at all but the Los Angeles Times (Table 9).

The percentage of overall entertainment articles went up between 1965 and 1975 at every newspaper except the Chicago Tribune (Table 4). Between 1975 and 1989, the percentage of these articles rose at The New York Times, the Washington Post and the Chicago Tribune, but fell at the Los Angeles Times. At all newspapers, the number of articles has risen between 1975 and 1989 to a point higher than 1965 . Looking at individual papers over time, there was a significant difference in the number of entertainment articles at the Washington Post, Chicago Tribune, and the Los Angeles 
Times. There was not enough data to perform a chi square analysis on the number of entertainment articles over time in The New York Times.

The individual story categories under entertainment articles, entertainment/arts and hobbies, also were analyzed. There was insufficient data to analyze the differences in number of articles about hobbies over time across newspapers. The percentage of entertainment/arts articles continued to increase from 1965 to 1975 to 1989 at all but the Chicago Tribune, where the percentage dropped between 1965 and 1975 before increasing again (Table 9). The numbers of entertainment/arts articles in 1989 at all four newspapers were greater than they were in 1975 or 1965 , although the increase at the Los Angeles Times was very small, from 58 in 1965, to 65 in 1975 , to 59 in 1989.

The percentage of syndicated articles at all newspapers in 1989 was greater than it had been in either 1965 or in 1975 (Table 4). The percentage of articles at The New York Times was so small as to be insignificant. The percentage and number of articles grew from 1965 to 1975 to 1989 at the Washington Post and at the Chicago Tribune. At the Los Angeles Times, the percentage and number of articles declined in 1975 before increasing in 1989.

There was not enough data to analyze differences in number of syndicated articles in each of the four newspapers over time. However, by removing consumer articles, which had two cells with expected frequency less than five, there was a significant difference in the number of syndicated articles in the Chicago Tribune over time (Appendix A). By removing articles about child rearing, which had three cells with an expected frequency less than five, there was a significant difference in the number of syndicated articles over time in the Los Angeles Times (Appendix A). Syndicated articles about personal advice and about hobbies also were analyzed. There was insufficient data to analyze syndicated articles about child rearing, health, 
consumer, fashion, and other topics. The New York Times was not included because of lack of sufficient data.

There was a significant difference in the number of syndicated articles on personal advice over time in the three newspapers (Appendix A). The number of articles at each paper in 1989 was higher than in either 1975 or 1965 . The percentage of articles grew slightly from 1965 to 1975 to 1989 at the Washington Post (Table 9). At the Chicago Tribune, the percentage increased between 1965 and 1975 and then decreased slightly in 1989 (Table 9), but the number of articles increased every year. At the Los Angeles Times, the percentage of articles stayed the same between 1965 and 1975 and then increased in 1989.

There was a significant difference in the number of syndicated articles about hobbies over time across the three newspapers (Appendix A). The most dramatic change occurred at the Chicago Tribune, where the percentage (Table 9) and number of articles dropped between 1965 and 1975 and then made a large jump between 1975 and 1989. At the Los Angeles Times, the number of articles dropped between 1965 and 1975 and then went up again in 1989. At the Washington Post, no articles were printed in 1965 and about the same number of articles were printed in 1975 and 1989.

As for articles about politics and other subjects not traditionally found in these sections, the numbers were greater in 1989 in all four newspapers than in 1965 or 1975. The percentages increased over time at all but The New York Times. At The Times, the percentage decreased slightly between 1975 and 1989 (Table 4).

Trends can be ascertained from all this analysis by looking at the changes shared by all four newspapers between 1975 and 1989. All four newspapers showed the same types of changes in entertainment, syndicated, lifestyle, and fashion articles; in articles 
about personal relationships, finances and purchases; and social events; and in articles about politics and other non-traditional feature subjects.

One trend is for "Features/entertainment Sections" to offer a greater number of entertainment articles. It becomes confusing to analyze just how much entertainment coverage is being included in "Features/Entertainment Sections" because some newspapers, such as the Boca Raton News, Santa Cruz Sentinel, and Orange County Register, publish a separate entertainment section under the umbrella of the "Features/Entertainment Section." But even at these papers, entertainment coverage is increasing in "Features," according to editors who were interviewed. White of the Commercial Appeal said sections have to increase this coverage "because readers are getting younger and have been weaned on MTV and Entertainment Tonight" (personal communication, May 19, 1991).

The number and percentage of syndicated articles rose in the late 1980s over the mid-1970s because of economic growth, because of editors' desires to offer more variety, and because there was more to chose from, according to editors interviewed. As White of the Commercial Appeal said:

There is more syndicated out there and more issues people are interested in today. We are using more syndicated. We subscribe to major news seryices and Scripps Howard has one of its own. You are always compelled to run them because they are so good and give readers practical information (personal communication, May 20, 1991).

The use of syndicated material also depends on the philosophy of the editor. Some editors prefer to use local over syndicated. Taylor, former editor of the Los Angeles Times' "View," said the section increased in syndicated coverage in 1989 because of the editor. She said: 
She had come from Atlanta and had this Eastern view you could include political stuff, that the "View" section wasn't local. There was a feeling that it was perfectly normal for them to take a story that national couldn't use that had a feature sense, but it wasn't local or lifestyle. It was just an interesting story. The recession and the subsequent cutback in space may cause some "Features/ Entertainment Sections" to reduce their use of syndicated materials. This already is occurring at the Orange County Register, according to associate editor Holland (personal communication, May 16, 1991).

The percentage of lifestyle articles, percentage and number of articles on personal relationships, and percentage of articles on finances and purchases, fashion, and social events decreased between 1975 and 1989 in the four newspapers studied. The trend in the $1990 \mathrm{~s}$, however, is to return to some of this coverage. Taylor, former editor of the Los Angeles Times' "View" section, said coverage of these areas decreased as editors attempted to attract the young, urban, professional market (personal communication, May 20, 1991). Articles on national personalities were popular, not articles about what made people live, she said. But Wada, the new "View" editor, is going back to lifestyle articles, specifically those on personal relationships, according to Taylor. A 1991 five-part series on preschools is being reprinted, she noted. "When you have enough people who want reprints, you know it has touched a big chord. That is a personal relationship story because it gets into how husbands and wives feel," she said. Kerwin of the Boca Raton News said her section has increased in all these areas in its effort to reach the 25-to-43-year-old market. The Commercial Appeal has increased its coverage in all these areas, editor White said, because:

Those are topics that people really care about. Personal concerns are important to people. We do more of those because that is what helps readers cope. The 
women's section of 20 years ago had some of that, but they didn't have the edge on the writing that newer reporters have (personal communication, May 20 , 1991).

\section{Changes In Emphasis on Gender}

Newspapers showed a decrease in emphasis on content appealing to women, and an increase in emphasis on content pertaining to men between 1975 and 1989 . The analysis showed a significant difference over time across newspapers in the number of articles about women, articles about men, articles about men and women, photos of women, photos of men, photos of men and women, ads targeted at women, and ads targeted at both men and women (Appendix A). There was too little data to analyze ads targeted at men.

The data indicates a drop in articles pertaining to women in most cases over time. Between 1975 and 1989, the percentage (Table 10) and the number of articles decreased at all but the Washington Post, where the percentage stayed about the same (1\% decrease) and the total number went up. Between 1965 and 1975, the number of articles decreased at all newspapers. The percentage stayed about the same at The New York Times and Chicago Tribune and decreased at the other two papers (Table 10).

What is noteworthy is that the percentage of articles about women in all four papers was way down in 1989 compared to 1965, while the percentage of articles about men grew steadily at all four newspapers from 1965 to 1975 to 1989 (Table 10). The numbers also have increased over time, except at the Chicago Tribune, where they decreased slightly between 1965 and 1975. 


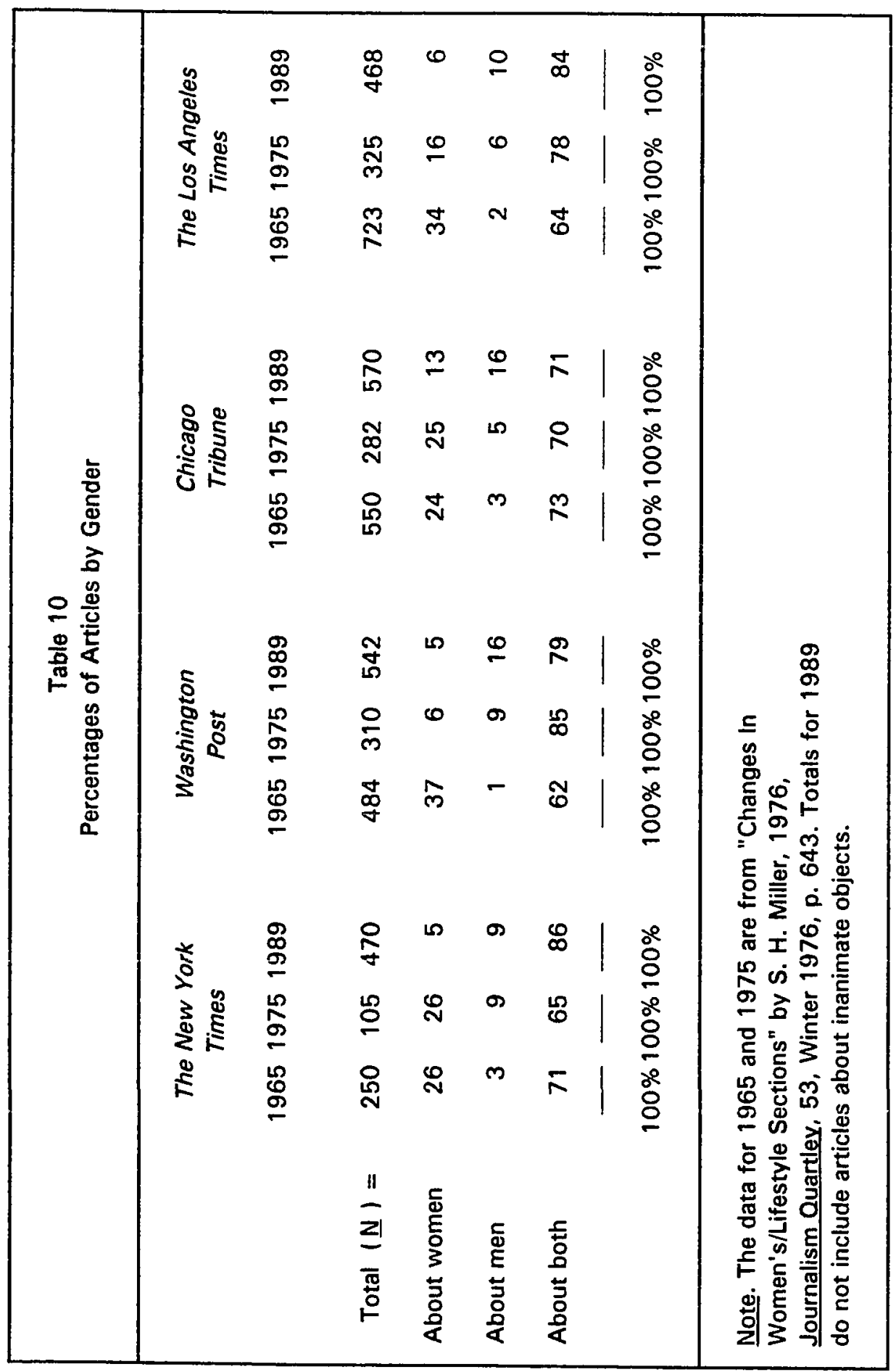


As for articles about men and women, only at the Los Angeles Times has the percentage of articles grown steadily over time (Table 10). But all papers except the Chicago Tribune show a greater percentage of these articles in 1989 than in any other year (Table 10). At the Chicago paper, the percentages stayed about the same over the years. As far as numbers, there were more articles about both men and women in 1989 than in any other year in all but the Los Angeles Times, where there were more articles in 1965.

A de-emphasis on content pertaining toward women also is shown in photo selection. The percentage of photos of women decreased or stayed about the same between 1975 and 1989, while the percentage of photos of men increased at each paper (Table 11). The number of photos of men also increased from 1965 to 1975 to 1989 at all but the Chicago Tribune, where it dropped slightly between 1965 and 1975.

The number of photos of women went down at all four papers between 1965 and 1975 and then went up between 1975 and 1989. The percentage of photos at all but The New York Times has gone down between 1975 and 1989 (Table 11). Between 1965 and 1975, the percentage of photos went down at all but the Chicago Tribune, where it stayed the same (Table 11).

The percentage of photos of both men and women has not changed much over (Table 11), but the numbers have. After the numbers of these photos fell at all four newspapers between 1965 and 1975, they increased between 1975 and 1989 .

There also was a significant difference across newspapers over time in total photos (Appendix A). At all four newspapers, the total number decreased between 1965 and 1975 and then increased between 1975 and 1989 (Table 11). 


\begin{tabular}{|c|c|c|c|c|c|c|c|c|}
\hline 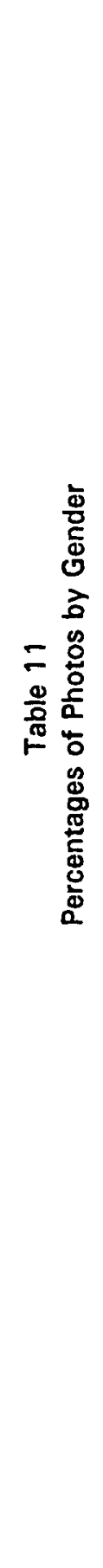 & 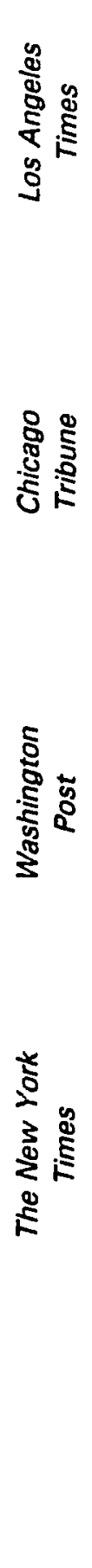 & 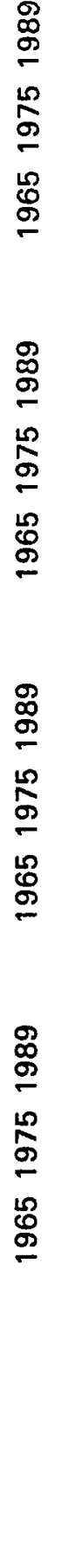 & 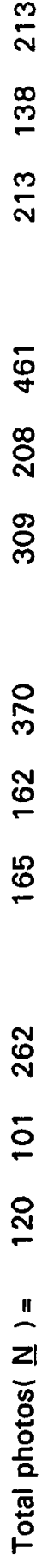 & 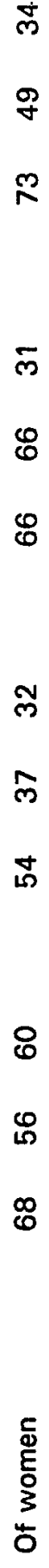 & $\begin{array}{l}\bar{N} \\
\tilde{N} \\
N\end{array}$ & $\begin{array}{l}\text { N } \\
\stackrel{L}{N} \\
\hat{m}\end{array}$ & 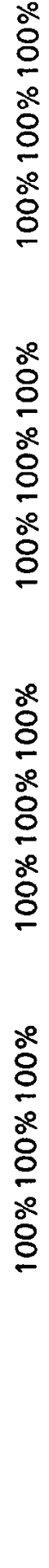 & 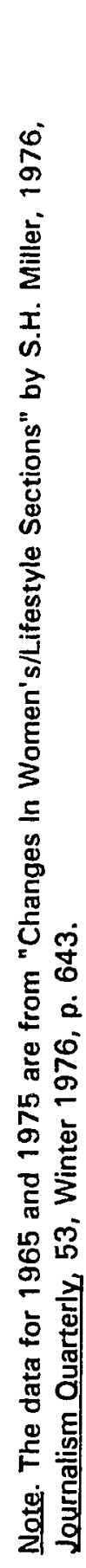 \\
\hline
\end{tabular}


The percentage of ads directed at women decreased from 1965 to 1975 to 1989 at all but The New York Times, where it went up between 1965 and 1975 (Table 12). The number of these ads decreased at all four newspapers over the years. The percentage of ads directed at both men and women has increased from 1965 to 1975 to 1989 at all but The New York Times, where it decreased between 1965 and 1975 (Table 12). At all four newspapers, the numbers of ads rose between 1975 and 1989 to higher than they had been in any of the three years. The number of ads has increased steadily over the three years studied at the Washington Post and at the Chicago Tribune.

There also was a significant difference across newspapers over time in the total number of ads (Appendix A). At all four newspapers, the number dropped between 1965 and 1975 and then increased between 1975 and 1989 to a point greater than in 1965 (Table 12).

These sections moved away from coverage, photos, and ads geared specifically toward women as part of the overall trend toward more variety. Varcados, editor of the "Features/Entertainment Section" at the Santa Cruz Sentinel, said the number of articles about women had declined "because we expanded our horizons. It wasn't a negative thing. We weren't trying to get away from women's coverage, but we wanted to do stories to cover the whole community" (personal communication, May 14, 1991). Holland, associate editor of the Orange County Register, said his section has broadened so that it no longer focuses on women (personal communication, May 17, 1991).

In the early 1990s, however, some sections are again gearing coverage toward women. Holland of the Orange County Register said his section in the next year or two will lean more toward attracting women. "Newspapers feel they have gone too far in broadening to where they are not attracting any one group. Men have the sports pages 


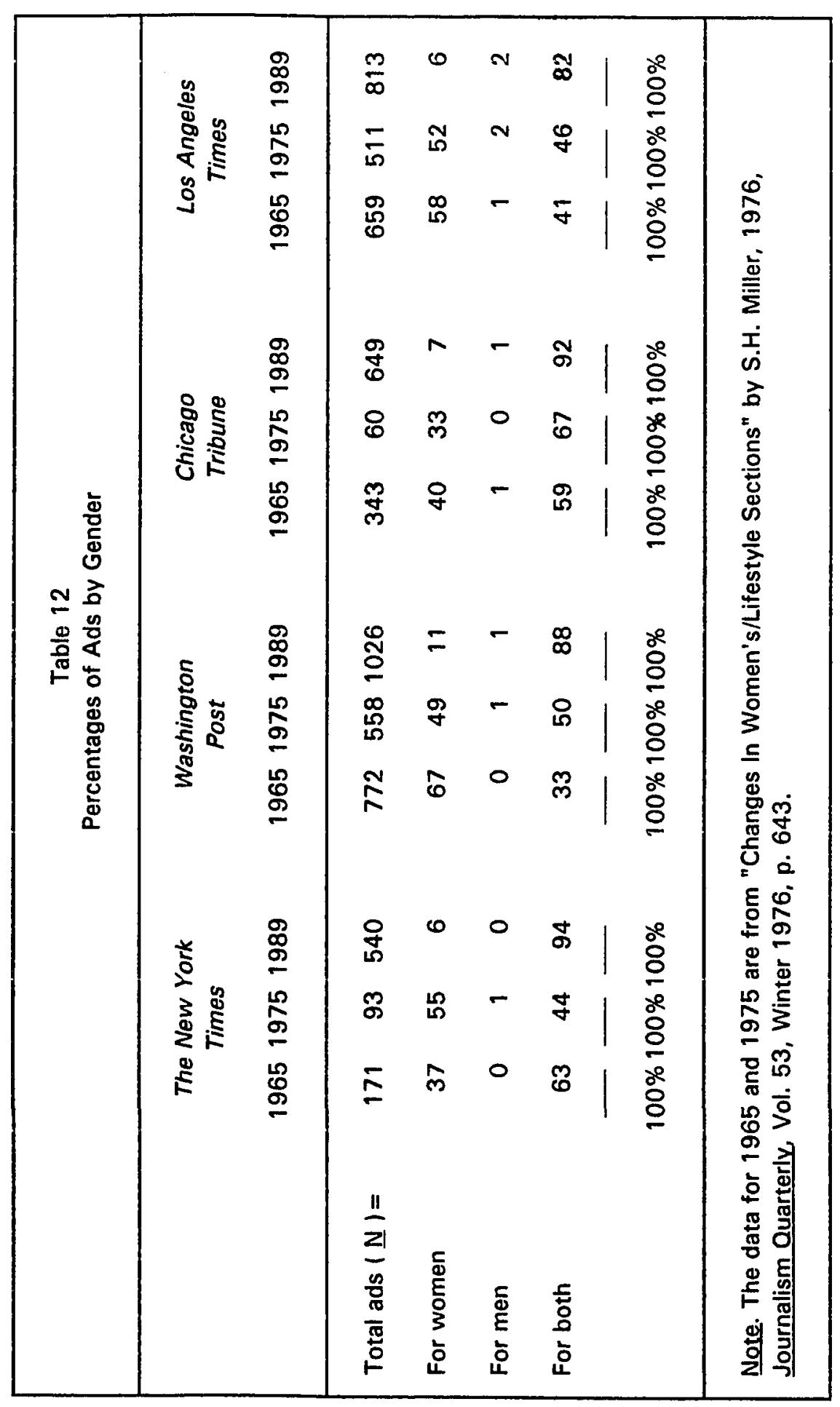


and business. We kind of lost the one section that women really read," he said (personal communication, May 16, 1991). Kerwin of the Boca Raton News, said:

Coverage geared toward women did decline over the past 14 years. . . . Again, that was to try to interest the non-traditional readers. But now we are contemplating additional ways to attract women readers because our research shows that they, more than any demographic group, are not reading the paper because they don't have the time. We are contemplating starting a section for women only, one day a week. Our parent and child section has done extensive stories on the working woman and how to juggle child care and career. Our business section has done a lot on women and careers. In our health section, we have done stories for women about making breast feeding work while you work (personal communication, May 17, 1991).

Surveys by the Commercial Appeal indicate readership by women is on an increase along with readership by men. But "Appeal" editor White said, "I wouldn't do a section geared to women. The only way to get back readership is to turn out a good newspaper" (personal communication, May 19, 1991).

New Areas of Analysis

Chi square was not used to analyze the number of articles on sex roles, articles on time saving, or graphics because these areas were not analyzed by Miller (1976). There were very few articles on sex roles and on time sharing. In The New York Times, there was one article on sex roles and two on time saving. In the Washington Post, there was one article on sex roles and none on time saving. In the Chicago Tribune, there were two articles on sex roles and one on time saving. In the Los Angeles Times, there was one article on sex roles and two on time saving. In the chi 
square analysis, they were included in the "politics and other" category. Since Miller (1976) did not analyze these types of articles separately, she would have included articles on sex roles and on time sharing in the "politics and other" category.

The newspapers were using graphics in 1989, but not as much as photos.

Except for The New York Times, there were a higher percentage and greater number of graphics of both men and women than any other category (Table 13). In The New York Times, there were a higher percentage and a greater number of graphics of inanimate objects than any other category.

Table 13

Percentages of graphics by gender in 1989

\begin{tabular}{|c|c|c|c|c|}
\hline & $\begin{array}{c}\text { The New York } \\
\text { Times }\end{array}$ & $\begin{array}{c}\text { Washington } \\
\text { Post } \\
\end{array}$ & $\begin{array}{l}\text { Chicago } \\
\text { Tribune }\end{array}$ & $\begin{array}{c}\text { Los Angeles } \\
\text { Times }\end{array}$ \\
\hline & $\underline{\mathbf{N}}=99$ & $\underline{N}=128$ & $\underline{N}=125$ & $\underline{N}=20$ \\
\hline Of women & 21 & 7 & 8 & 15 \\
\hline Of men & 14 & 6 & 10 & 5 \\
\hline Of both & 20 & 59 & 43 & 65 \\
\hline Of inanimate objects & 45 & 28 & 39 & 15 \\
\hline Total & $\overline{100 \%}$ & $\overline{100 \%}$ & $\overline{100 \%}$ & $\overline{100 \%}$ \\
\hline
\end{tabular}




\section{CHAPTER V}

\section{CONCLUSIONS}

After studying the changes from "Women's Pages" to "Lifestyle Sections" between 1965 and 1975, Miller (1976) concluded "there do not appear to have been major changes in lifestyle coverage" (p. 647). However, between 1975 and 1989 when these sections evolved into "Features/Entertainment Sections," several changes in coverage were shared by all four newspapers - The New York Times, Washington Post, Chicago Tribune, and Los Angeles Times. It is these significant changes shared by all four newspapers that indicate the trends occurring between 1975 and 1989 in "Features/Entertainment Sections." In some cases, significant changes were evident in three out of the four newspapers studied, but it is the trends shown in all four of these major newspapers that truly demonstrate what has happened with these sections.

The significant changes shared by all four papers were: an increase in size; an increase in the number of entertainment, syndicated, and political and other nontraditional feature articles; a decrease in overall lifestyle articles; a decrease in articles about personal relationships, finances and purchase, fashion, and social events; a decrease in content directed at women; a continuation of the increase in content directed at both sexes that began with the changes in the mid-1960s; and an increase in the total numbers of photos and ads.

The increase in size is a reflection of the healthy economy of the late 1980 s. As the economy expanded, newspapers received more advertising, and newspapers in general increased in size. However, just because newspapers grow in size does not mean certain sections also increase. If a newspaper chooses to de-emphasize a certain section, it can decrease while more "popular" sections increase. This is what Miller 
(1976) discovered. Between 1965 and 1975, these sections decreased in size while "Entertainment Sections" increased, Miller noted. All 1989 sections were larger than their 1975 counterparts. They even were larger than the "Women's Pages" of 1965 except for the Los Angeles Times (Table 4). Not only had the number of stories increased, but the average number of lifestyle pages in 1989 was greater at all newspapers than in 1965 or 1975 . This shows that editors were putting a greater emphasis on "Features/Entertainment Sections."

The increase in size in "Features/Entertainment Sections" may be a reflection of newspaper managements' efforts to capture the youth market with more entertainment coverage. Entertainment articles increased at all four papers from 1975 to 1989. Newspapers are going after the under-age-30 market because they tend to be at-risk readers, those most likely to drop their newspaper reading habit because of lack of time, or to be potential readers, those who are not reading the paper, but would if it were more to their liking (American Society of Newspaper Editors, 1991). The increase in photographs, in keeping with the increase in size, also might be an indication of this desire to attract the generation that was brought up on television.

These sections, as some writers were predicting (e.g., Editor \& Publisher, 1980; Archbold, 1982; Rykken, 1988), did not revert to traditional content to recapture the women readers they lost when they went from "Women's Pages" to "Lifestyle Sections." This would be in keeping with their effort to pull in the under-30, male and female readers, who wouldn't be interested in traditional content. Food articles did not made a comeback since decreasing between 1965 and 1975, and neither did fashion. Articles on social events continued the decline that Miller noted in 1976. Nontraditional subjects, such as politics, were on the rise at all four papers. Articles, 
photos, and ads geared specifically toward women, a mainstay of the traditional "Women's Pages," all declined between 1975 and 1989.

These sections also lost some of the content that defined them in the mid-1970s as the new "Lifestyle Sections." The dominant philosophy at the time, according to Miller (1976), "was that the women's pages should become lifestyle sections - focusing on both men and women, and dealing with the concerns of average citizens, such as consumer topics and changes in male and female roles" (p. 641). One of the only things left was the continued focus on both men and women. These sections dropped much of their lifestyle coverage, particularly those articles about personal relationships. Consumer topics also declined, with fewer articles about finance and purchases. There was less "news you can use" recommended by Miller (1989). Not only were articles about finances and purchases down at all four newspapers, but the percentages of articles about child rearing were extremely low ( $2 \%$ or less) at all four papers.

The sections of the 1990s should drop their youth focus and go after women, particularly women in their $20 \mathrm{~s}, 30 \mathrm{~s}$ and early $40 \mathrm{~s}$. Women are declining as newspaper readers at a greater rate than men (Simmons Market Research Bureau, 1990). The entire newspaper should be revamped to attract female readers, but this may be asking too much of the male-dominated newspaper management. The "Features/Entertainment Section" of the 1990s is the perfect place to start because women traditionally have made up the majority of readers of this section (Newspaper Advertising Bureau, 1988).

These sections in particular should go after baby-boomer women, those born between 1946 and 1964. Baby boomers, both men and women, will continue to make up over a fifth of the U.S. population into the 21 st Century and there are more babyboomer women than men, according to U.S. Census predictions (Spencer, 1984). The U.S. population is getting older because baby-boomers are aging, so it is a waste for 
these sections to continue going after youth (18-24) into the next decade. The KnightRidder newspaper chain is right on target with its $25-43$ project in the Boca Raton (FL) News. The entire paper has been revamped to attract baby boomers, those born between 1946 and 1964, including the "Features/Entertainment Section" known as "Essentials." Knight-Ridder management realized how important this section is to this age group, making the make-over of "Essentials" the second biggest change in the newspaper next to eliminating stories that jump from page to page, according to "Essentials" editor Kerwin. Management saw that this was the best section to attract these baby boomers, the majority of whom are in their $20 \mathrm{~s}$ and $30 \mathrm{~s}$, the same age group that makes up the majority of at-risk and potential readers of newspapers (American Society of Newspaper Editors, 1991).

"Features/Entertainment Section" editors of the 1990s are aware of the mistakes that were made and are beginning to try to rectify them. This is seen in the growing interest of section editors in gearing more of their content toward women and even in establishing weekly "Women's Sections" as part of the "Features/Entertainment Sections." The editor of the Orange County Register stated he expects his section in the next year or two to be leaning more toward the interests of women. "Women's Sections" have been commissioned and tested the past two years by the American Society of Newspaper Editors, and earned positive responses from test groups of readers. A weekly section, "Sunday Woman," which could be ordered by newspapers through King Features Syndicate, doubled in circulation from 1982 to 1987, when it folded because of economic conditions.

A weekly section aimed at women, however, may not be the answer. Women need to be attracted to the newspaper on a daily basis, not just once a week. These sections need to include articles every day to attract women readers. Editors can 
discover what kinds of subjects attract women readers by picking up one of the popular women's magazines. Readership of these magazines is on the increase at the same time readership by women of newspapers continues to decline, according to Chetan Shah of Mediamark Research Inc. (personal communication, July 15, 1991).

If these sections do their job, they will continue to cover the changing lifestyles of the American public. As women moved out of the homes and into the work force, these sections needed to change from "Women's Pages" to "Lifestyle Sections," reflecting the fact that there were many areas of interest to both men and women. Today, as baby boomers mature and grapple with the conflicts of work and raising families, these sections again need to make changes. This ever-changing character of the "Features/Entertainment Section" opens the door to future research possibilities.

\section{Directions for Further Research}

The main reason more study is needed on these sections is because they are the prime area of newspapers to attract women readers, particularly those in their 20 s and $30 \mathrm{~s}$, the age group that makes up the majority of the baby-boomer market (Spencer, 1984). Now that some sections are considering gearing themselves more toward women, or even starting weekly "Women's Sections," study needs to be done on whether these efforts will increase readership by women. In order to insure that these new "Women's Sections" will attract readers, study also needs to be done on what women want in newspapers. Focus groups of women should be formed to evaluate newspapers and to compare their content to what is offered in women's magazines, which are gaining in readership. Research should also be done on the amount of women's coverage newspapers are offering in general. Such studies could be used to 
revamp entire newspapers, not just the "Features/Entertainment Sections," to attract female readers.

Further content analysis of "Features/Entertainment Sections" also is needed because editors are saying that they are returning to some of the content that declined between 1975 and 1989 such as lifestyle articles, and articles about personal relationships, finances and purchases, fashion, and social events. Study could be done on whether sections are increasing content in these areas, why they are doing so, and if these efforts increase readership.

Study also is needed on what younger, female readers want in this section. If the sections are revamped to attract women readers, these younger readers are important because they will replace other readers as they age. 


\section{REFERENCES}

Abarbanel, S. \& Peterson, K. (1989, March 14). Never enough time? You can beat the clock. Family Circle, pp. 115-117, 132, 134, 136.

American Association of University Women. (1974). A quantitative analysis of the "Day" section of the Portland Oregonian by study groups of the Beaverton and Portland branches, American Association of University Women. (Available from B. Underwood, 6336 SW Tower Way, Portland, OR, 97221)

American Society of Newspaper Editors. (1990, April). Prototypes for the future: how readers look at newspapers (Future of newspapers report). Washington, D.C.: Author.

American Society of Newspaper Editors. (1991, April). Keys to our survival (Future of newspapers report). Washington, D.C.: Author.

Anderson, R. (1974). Press coverage of women. Montana Journalism Review, pp. 219.

Archbold, R. (1982, November). Is it the family section or Women's, or Tempo, or Savvy or People or whatever? APNE Follow-up Committee, p. 10.

Astor, D. (1989, October 28). They look at ways to find more readers. Editor \& Publisher, 122, 50-52.

Baca, C. M. (1975, May). How newspapers' women's pages changed over time, 1953-1974; a content analysis of the three San Francisco Bay Area daily newspapers. Unpublished master's thesis, San Jose State University, San Jose, CA.

Battelle Human Affairs Research Centers. (1987). The "Cosmopolitan" report: the changing life course of America Women. (Part 3: Consumer Behavior). Seattle, WA: Author.

Behrmann, J. (1988, October). The Desert Sun rises with living. Attack of the Feature Creature, 1988 APME Convention, (pp. 37-39). Boston, MA.

Bureau of Advertising. (1972, December). A national survey of the content and readership of the American newspaper. New York, NY: Author.

Carlson, P. G. (1975, May 31). Are women's pages getting better? Editor \& Publisher, 108, 11. 
Chakravarty, S. N. \& Torcellini, C. (1989, February 20). Citizen Kane meets Adam Smith. Forbes, pp. 82-85.

Chang, W. H. (1975, Spring). Characteristics and self perceptions of women's page editors. Journalism Quarterly, 52, 61-65.

Cook, A. (1973, February). Urban renewal for the female ghetto. Houston Journalism Review, 1(9), 1-5.

D'Arcy, R. (1984, August). A shift from reporting for women to reporting for people. ASNE Bulletin, p. 8.

Diamond, E. (1971). Women and the reportorial revolution. What's Wrong With Women's Pages? University of Chicago: Center for Policy Study, 9-15.

Dishon, C. (1971). The tea party was over a long time ago; please take the tea cups away. What's Wrong With Women's Pages? University of Chicago: Center for Policy Study, 16-21.

Finney, M. (1983). Lifestyle section is a place to experiment. Modern Living: The 1983 Final Report of the Modern Living Committee of the Associated Press Managing Editors, pp. 17-19.

Fischl, I. (1988, April 15). The hidden news on society pages. The New York Times, p. 27.

Fitzgerald, M. (1984, October 20). Mixed bag. Editor \& Publisher, 117, 17, 27.

Guenin, Z. B. (1985, Spring). Women's pages in American newspapers: missing out on contemporary content. Journalism Quarterly, 62, 66-69.

Horgan, D. (1983, May). Liberating the women's page. Washington Journaism Review, pp. 18-21.

Houck, J. I. (1984, August). Keep in mind that the audience is women. ASNE Bulletin, p. 16.

How they would liberate the women's pages from drab content. (1971, May 1). Editor \& Publisher, 104, 9-11.

Kampinsky, E. (1984, August). Target lifestyles sections to win readers of the future. ASNE Bulletin, pp. 4-5. 
Kozdemba, K. (1988, October). Between magazine covers: inside thinking on feature sections. Attack of the Feature Creature, 1988 APME Convention, (pp. 2-9). Boston, MA.

Laventhol, D. (1984, August). Once and future lifestyles sections. ASNE Bulletin, p. 10.

Luebke, B. F. (1985, Summer). News about women on the A wire. Journalism Quarterly, 62, 329-333.

Magazine Publishers Association Handbook. (1990-91). Nearly everyone reads magazines, p. 31. New York, NY: Author.

Merritt, S. \& Gross, H. (1978, Fall). Women's page/lifestyle editors: does sex make a difference? Journalism Quarterly, 55, 508-514.

Meyers, J. (1990, April 16) Papers re-invent women's section. Advertising_Age, p. 57.

McGehee, S. (1988, October). Putting new life into lifestyle. Attack of the Feature Creature, 1988 APME Convention, (pp. 10-12). Boston, MA.

Miller, S. H. (1976, Winter). Changes in women's/lifestyle sections. Joumalism Quarterly, 53, 641-647.

Miller, S. H. (1987, Spring). America's dailies and the drive to capture lost readers. Gannett Center Journal, pp. 56-68.

Miller, S. H. (1989, Spring). Women's lifestyles: a special report. Scripps Howard Editors Newsletter. (Available from Scripps Howard, P.O. Box 5380, Cincinnati, $\mathrm{OH}, 45201$ )

Miller, S. H. (1990, April). Rethinking features sections: what readers want in the 1990s. Scripps Howard Editors Newsletter. (Available from Scripps Howard, P.O. Box 5380, Cincinnati, OH, 45201)

Mills, K. (1988). A Place In the News: From the Women's Pages to the Front Pages. New York: Dodd Mead.

Newspaper Advertising Bureau, Inc. (1980). The Sunday newspaper: a five-market study. New York, NY: Author.

Newspaper Advertising Bureau, Inc. (1988). News and newspaper reading habits: results from a national survey. New York, NY: Author. 
Pierce, K. M. (1980, May 20) Our lives making major news across the nation. Adweek, pp. 17-19.

Portrait of a lifestyle editor. (1981, October 20-23). An APME Modern Living Committee Report, (pp. 3-5). Toronto, Ontario, Canada.

Radolf, A. (1980, March 1). Feature section blends hard and soft news. Editor \& Publisher, 113, 40-41.

Rucker, B. W. (1971). Peddling the phony American dream. What's Wrong With Women's Pages? University of Chicago: Center for Policy Study, 22-26.

Rykken, R. (1988, July). Hi, society! Presstime, pp. 6-8.

Rykken, R. (1989, March). Readership decline brings newspapers to crossroads. Presstime, pp. 22-24.

Scott, P. B. (1987, September). Lifestyle moves from coping to quality. APME Features Committee Report, p. 2.

Sidlo, S. (1988, October). Listen to the syndicate reps: they're plugged into your readers. Attack of the Feature Creature, 1988 APME Convention, (pp. 42-43). Boston, MA.

Simmons Market Research Bureau. (1990). Study of Media and Markets. (Available from Simmons Market Research Bureau, 380 Madison Ave., New York, NY, 10017)

Spencer, G. (1984, May). Projections of the population of the United States by age, sex and race: 1983 to 2080, 952, U.S. Department of Commerce, Bureau of the Census, Washington, D.C.

Tobin, R. L. (1971, September 11). What's wrong with the woman's page? SR Communications, pp. 57-58.

Tompkin, E. (1988, October). Luring the marginal reader. Attack of the Feature Creature, 1988 APME Convention, (pp. 40-41). Boston, MA.

Van Gelder, L. (1974, November). Women's pages: you can't make news out of a silk purse. Ms., pp. 112-116.

Von Hoffman, N. (1971). Why should women's editors ride in the back of the bus? What's Wrong With Women's Pages?, University of Chicago: Center for Policy Study, 3-8. 
Where some of the seven sisters audience has gone. (1989, July 26). Media Industry Newsletter. (Available from Media Industry Newsletter, 145 E. 49th St., New York, NY, 10017)

Women-oriented supp service offered by King. (1980, December 13). Editor \& Publisher, 113, 28.

Wood, F. W. (Ed.). (1989). An American profile - opinions and behavior, 19721989. Detroit: Gale Research.

Zophy, A. H. with Kavenik, F. M. (Eds.). (1990). Handbook of American women's history. New York: Garland. 
APPENDIX A:

Chi Square Tables and Results Showing Significant Differences Over Time Across Newspapers and Over Time in Individual Newspapers

Total lifestyle articles over time across newspapers

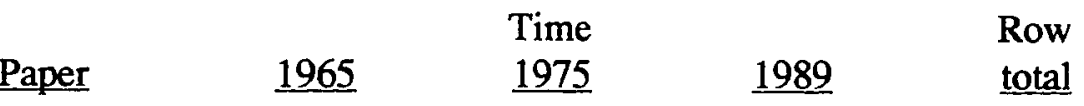

$\begin{array}{lllll}\text { The New York Times } & 30 & 40 & 20 & 90\end{array}$

$\begin{array}{lllll}\text { Washington Post } & 82 & 31 & 40 & 153\end{array}$

$\begin{array}{lllll}\text { Chicago Tribune } & 55 & 45 & 67 & 167\end{array}$

$\begin{array}{lllll}\text { Los Angeles Times } & 29 & 52 & 50 & 131\end{array}$

$\begin{array}{lllll}\text { Column Total } & 196 & 168 & 177 & 541\end{array}$

$X^{2}(6, \underline{N}=541)=44.65, \underline{p}<.005$

Total consumer articles over time across newspapers

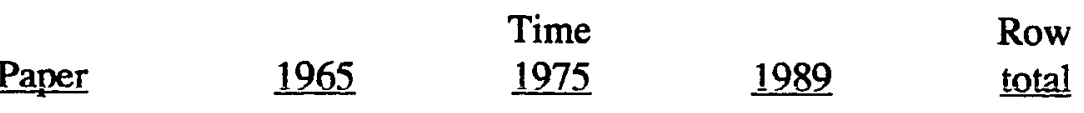

$\begin{array}{lllll}\text { The New York Times } & 23 & 18 & 67 & 108\end{array}$

$\begin{array}{lllll}\text { Washington Post } & 25 & 31 & 12 & 68\end{array}$

$\begin{array}{lllll}\text { Chicago Tribune } & 39 & 42 & 35 & 116\end{array}$

$\begin{array}{lllll}\text { Los Angeles Times } & 15 & 29 & 65 & 109\end{array}$

$\begin{array}{lllll}\text { Column Total } & 102 & 120 & 179 & 401\end{array}$

$\mathrm{X}^{2}(6, \underline{\mathrm{N}}=401)=56.25, \underline{\mathrm{p}}<.005$ 
Total food articles over time across newspapers

\begin{tabular}{lrrrr}
\multicolumn{1}{c}{ Paper } & $\underline{1965}$ & $\underline{1975}$ & $\underline{1989}$ & $\underline{\text { total }}$ \\
The New York Times & 33 & 9 & 54 & 96 \\
Washington Post & 5 & 3 & 1 & 9 \\
Chicago Tribune & 61 & 23 & 0 & 84 \\
Los Angeles Times & 15 & 0 & 2 & 17 \\
Column Total & 114 & 35 & 57 & 206 \\
& & & & \\
& $\mathrm{X}^{2}(6, \underline{\mathrm{N}}=206)=82.43, \mathrm{p}<.005$ &
\end{tabular}

Total fashion articles over time across newspapers

\begin{tabular}{lrrrr}
\multicolumn{1}{c}{ Paper } & $\underline{1965}$ & $\underline{1975}$ & $\underline{1989}$ & $\begin{array}{r}\text { Row } \\
\text { total }\end{array}$ \\
The New York Times & 47 & 14 & 26 & 87 \\
Washington Post & 19 & 9 & 15 & 43 \\
Chicago Tribune & 49 & 17 & 4 & 70 \\
Los Angeles Times & 28 & 26 & 17 & 71 \\
Column Total & 143 & 66 & 62 & 271
\end{tabular}

$$
\mathrm{X}^{2}(6, \underline{\mathrm{N}}=271)=27.61, \underline{\mathrm{p}}<.005
$$




\begin{tabular}{|c|c|c|c|c|}
\hline \multicolumn{5}{|c|}{ Total social articles over time across newspapers } \\
\hline Paper & 1965 & $\begin{array}{l}\text { Time } \\
\underline{1975}\end{array}$ & 1989 & $\begin{array}{l}\text { Row } \\
\text { total }\end{array}$ \\
\hline The New York Times & 95 & 12 & 211 & 318 \\
\hline Washington Post & 276 & 53 & 48 & 377 \\
\hline Chicago Tribune & 132 & 39 & 47 & 218 \\
\hline Los Angeles Times & 484 & 101 & 79 & 664 \\
\hline Column Total & 987 & 205 & 385 & 1577 \\
\hline \multicolumn{5}{|c|}{$\mathrm{X}^{2}(6, \underline{\mathrm{N}}=1,577)=393.74, \mathrm{p}<.005$} \\
\hline
\end{tabular}

\begin{tabular}{|c|c|c|c|c|}
\hline \multicolumn{5}{|c|}{ Total entertainment articles over time across newspapers } \\
\hline Paper1965 & $\underline{1975}$ & $\begin{array}{l}\text { Time } \\
1989 \\
\end{array}$ & total & Row \\
\hline The New York Times & 7 & 4 & 84 & 95 \\
\hline Washington Post & 24 & 127 & 254 & 405 \\
\hline Chicago Tribune & 126 & 37 & 222 & 385 \\
\hline Los Angeles Times & 58 & 68 & 78 & 204 \\
\hline Column Total & 215 & 236 & 638 & 1089 \\
\hline \multicolumn{5}{|c|}{$X^{2}(6, \underline{N}=1,089)=186.84, \underline{p}<.005$} \\
\hline
\end{tabular}


Total syndicated articles over time across newspapers

$\begin{array}{lllll} & \text { Time } & & \text { Row } \\ \text { Paper } & 1965 & \underline{1975} & \underline{1989} & \underline{\text { total }}\end{array}$

The New York Times

0

0

4

4

Washington Post

19

34

113

166

Chicago Tribune

83

79

205

367

Los Angeles Times

87

33

148

268

Column Total

189

146

470

805

$$
\mathrm{X}^{2}(6, \underline{\mathrm{N}}=805)=33.78, \mathrm{p}<.005
$$

Total articles about politics and other topics over time across newspapers

$\begin{array}{llll}\text { Paper } & \underline{1965} & \begin{array}{l}\text { Time } \\ 1975\end{array} \quad \underline{1989} \quad \underline{\text { Row }} \\ \text { total }\end{array}$

$\begin{array}{lllll}\text { The New York Times } & 15 & 8 & 30 & 53\end{array}$

$\begin{array}{lllll}\text { Washington Post } & 34 & 22 & 100 & 156\end{array}$

$\begin{array}{lllll}\text { Chicago Tribune } & 5 & 0 & 40 & 45\end{array}$

$\begin{array}{lllll}\text { Los Angeles Times } & 7 & 16 & 107 & 130\end{array}$

$\begin{array}{lllll}\text { Column Total } & 61 & 46 & 277 & 384\end{array}$

$$
\mathrm{X}^{2}(6, \underline{\mathrm{N}}=384)=31.44, \mathrm{p}<.005
$$


Total articles over time across newspapers

\begin{tabular}{lcccr}
\multicolumn{1}{c}{ Paper } & $\underline{1965}$ & $\underline{1975}$ & $\underline{1989}$ & $\begin{array}{r}\text { Row } \\
\text { total }\end{array}$ \\
The New York Times & 250 & 105 & 496 & 851 \\
Washington Post & 484 & 310 & 583 & 1377 \\
Chicago Tribune & 550 & 282 & 620 & 1452 \\
Los Angeles Times & 723 & 325 & 546 & 1594 \\
Column Total & 2007 & 1022 & 2245 & 5274 \\
& & & & \\
& $\mathrm{X}^{2}(6, \underline{\mathrm{N}}=5,274)$ & $=147.12, \mathrm{p}<.005$ &
\end{tabular}

Articles about personal relationships over time across newspapers

\begin{tabular}{lrrrr}
\multicolumn{1}{c}{ Paper } & $\underline{1965}$ & $\underline{1975}$ & $\underline{1989}$ & $\begin{array}{l}\text { Row } \\
\text { total }\end{array}$ \\
The New York Times & 0 & 11 & 4 & 15 \\
Washington Post & 19 & 19 & 2 & 40 \\
Chicago Tribune & 27 & 20 & 17 & 64 \\
Los Angeles Times & 7 & 23 & 10 & 40 \\
Column Total & 53 & 73 & 33 & 159 \\
& & & & \\
& & &
\end{tabular}


Articles about work/work relationships over time across newspapers

$\begin{array}{lllll} & \text { Time } & & \text { Row } \\ \text { Paper } & \underline{1965} & \underline{1975} & \underline{1989} & \underline{\text { total }}\end{array}$

$\begin{array}{lllll}\text { The New York Times } & 10 & 15 & 7 & 32\end{array}$

$\begin{array}{lllll}\text { Washington Post } & 24 & 9 & 33 & 66\end{array}$

$\begin{array}{lllll}\text { Chicago Tribune } & 6 & 11 & 42 & 59\end{array}$

$\begin{array}{lllll}\text { Los Angeles Times } & 15 & 16 & 34\end{array}$

$\begin{array}{lllll}\text { Column Total } & 55 & 51 & 116 & 222\end{array}$

$\mathrm{X}^{2}(6, \underline{\mathrm{N}}=222)=30.06, \underline{\mathrm{p}}<.005$

Child rearing articles over time across newspapers

\begin{tabular}{lrrrr}
\multicolumn{1}{c}{ Paper } & $\underline{1965}$ & $\underline{1975}$ & $\underline{1989}$ & $\begin{array}{r}\text { Row } \\
\text { total }\end{array}$ \\
$\begin{array}{lrrr}\text { The New York Times } \\
\text { Washington Post }\end{array}$ & 20 & 14 & 9 & 43 \\
Chicago Tribune & 22 & 3 & 5 & 47 \\
Los Angeles Times & 7 & 14 & 8 & 44 \\
Column Total & 88 & 44 & 6 & 26 \\
\end{tabular}

$$
X^{2}(6, \underline{N}=160)=26.31, \underline{p}<.005
$$


Health articles over time across newspapers

\begin{tabular}{lrrrr}
\multicolumn{1}{c}{ Paper } & $\underline{1965}$ & $\underline{1975}$ & $\underline{1989}$ & $\begin{array}{r}\text { Row } \\
\text { total }\end{array}$ \\
The New York Times & 0 & 3 & 9 & 12 \\
Washington Post & 10 & 13 & 2 & 25 \\
Chicago Tribune & 5 & 20 & 32 & 57 \\
Los Angeles Times & 0 & 16 & 41 & 57 \\
Column Total & 15 & 52 & 84 & 151 \\
& & & & \\
& $\mathrm{X}^{2}(6, \underline{\mathrm{N}}=151)=46.63, \mathrm{p}<.005$ &
\end{tabular}

Articles about finances and purchases over time across newspapers

\begin{tabular}{|lcccc|}
\hline \multicolumn{5}{|c}{ Articles about finances and purchases over time across newspapers } \\
& \multicolumn{5}{c}{ Time } & Row \\
Paper & $\underline{1965}$ & $\underline{1975}$ & $\underline{1989}$ & $\underline{\text { total }}$ \\
The New York Times & 8 & 12 & 22 & 42 \\
Washington Post & 5 & 9 & 2 & 16 \\
Chicago Tribune & 17 & 14 & 2 & 33 \\
Los Angeles Times & 7 & 13 & 18 & 38 \\
Column Total & 37 & 48 & 44 & 129 \\
& & &
\end{tabular}


Articles about social events over time across newspapers

\begin{tabular}{|c|c|c|c|c|}
\hline Paper & $\underline{1965}$ & $\begin{array}{l}\text { Time } \\
\underline{1975}\end{array}$ & $\underline{1989}$ & $\begin{array}{l}\text { Row } \\
\text { total }\end{array}$ \\
\hline The New York Times & 37 & 12 & 21 & 70 \\
\hline Washington Post & 232 & 50 & 20 & 302 \\
\hline Chicago Tribune & 110 & 39 & 6 & 155 \\
\hline Los Angeles Times & 354 & 59 & 77 & 490 \\
\hline Column Total & 733 & 160 & 124 & 1017 \\
\hline
\end{tabular}

Engagement/wedding articles over time across newspapers

$\begin{array}{lllll}\text { Paper } & \text { Time } & & \text { Row } \\ & 1965 & \underline{1975} & \underline{1989} & \underline{\text { total }}\end{array}$

$\begin{array}{lllll}\text { The New York Times } & 58 & 0 & 190 & 248\end{array}$

$\begin{array}{lllll}\text { Washington Post } & 44 & 3 & 28 & 75\end{array}$

$\begin{array}{lllll}\text { Chicago Tribune } & 22 & 0 & 41 & 63\end{array}$

$\begin{array}{lllll}\text { Los Angeles Times } & 130 & 42 & 2 & 174\end{array}$

$\begin{array}{lllll}\text { Column Total } & 254 & 45 & 261 & 560\end{array}$

$\mathrm{X}^{2}(6, \underline{\mathrm{N}}=560)=277.60, \underline{\mathrm{p}}<.005$ 
Entertainment/arts articles over time across newspapers

$\begin{array}{lllll} & \text { Time } & & \text { Row } \\ \text { Paper } & \underline{1965} & \underline{1975} & \underline{1989} & \underline{\text { total }}\end{array}$

The New York Times

23

63

68

Washington Post

19

121

249

389

Chicago Tribune

121

Los Angeles Times

58

31

213

365

Column Total

200

65

59

182

220

584

1004

$$
X^{2}(6, \underline{N}=1,004)=206.36, \underline{p}<.005
$$

Articles about women over time across newspapers

\begin{tabular}{lrrrr}
\multicolumn{1}{c}{ Paper } & $\underline{1965}$ & $\underline{1975}$ & $\underline{1989}$ & $\begin{array}{r}\text { Row } \\
\text { total }\end{array}$ \\
The New York Times & 65 & 27 & 24 & 116 \\
Washington Post & 179 & 19 & 28 & 226 \\
Chicago Tribune & 132 & 71 & 74 & 277 \\
Los Angeles Times & 246 & 52 & 25 & 323 \\
Column Total & 622 & 169 & 151 & 942
\end{tabular}

$$
X^{2}(6, \underline{N}=942)=86.93, \underline{p}<.005
$$




\begin{tabular}{|c|c|c|c|c|}
\hline \multicolumn{5}{|c|}{ Articles about men over time across newspapers } \\
\hline Paper & $\underline{1965}$ & $\begin{array}{l}\text { Time } \\
1975 \\
\end{array}$ & $\underline{1989}$ & $\begin{array}{l}\text { Row } \\
\text { total }\end{array}$ \\
\hline The New York Times & 8 & 10 & 43 & 61 \\
\hline Washington Post & 5 & 28 & 86 & 119 \\
\hline Chicago Tribune & 17 & 14 & 90 & 121 \\
\hline Los Angeles Times & 14 & 19 & 49 & 82 \\
\hline Column Total & 44 & 71 & 268 & 383 \\
\hline \multicolumn{5}{|c|}{$X^{2}(6, \underline{N}=383)=16.08, \underline{p}<.005$} \\
\hline
\end{tabular}

\begin{tabular}{|c|c|c|c|c|}
\hline \multicolumn{5}{|c|}{ Articles about both men and women over time across newspaper } \\
\hline Paper & 1965 & $\begin{array}{l}\text { Time } \\
\underline{1975}\end{array}$ & $\underline{1989}$ & $\begin{array}{l}\text { Row } \\
\text { total }\end{array}$ \\
\hline The New York Times & 177 & 68 & 403 & 648 \\
\hline Washington Post & 300 & 263 & 428 & 991 \\
\hline Chicago Tribune & 401 & 197 & 406 & 1004 \\
\hline Los Angeles Times & 463 & 254 & 394 & 1111 \\
\hline Column Total & 1341 & 782 & 1631 & 3754 \\
\hline \multicolumn{5}{|c|}{$\mathrm{X}^{2}(6, \underline{\mathrm{N}}=3,754)=159.53, \underline{\mathrm{p}}<.005$} \\
\hline
\end{tabular}




\begin{tabular}{|c|c|c|c|c|}
\hline \multicolumn{5}{|c|}{ Photos of women over time across newspapers } \\
\hline Paper & $\underline{1965}$ & $\begin{array}{l}\text { Time } \\
1975 \\
\end{array}$ & $\underline{1989}$ & $\begin{array}{l}\text { Row } \\
\text { total }\end{array}$ \\
\hline The New York Times & 82 & 57 & 157 & 296 \\
\hline Washington Post & 89 & 60 & 119 & 268 \\
\hline Chicago Tribune & 204 & 137 & 142 & 483 \\
\hline Los Angeles Times & 155 & 68 & 73 & 296 \\
\hline Column Total & 530 & 322 & 491 & 1343 \\
\hline \multicolumn{5}{|c|}{$X^{2}(6, \underline{N}=1,343)=78.22, \underline{p}<.005$} \\
\hline
\end{tabular}

\begin{tabular}{|lcccc|}
\hline \multicolumn{5}{c}{ Photos of men over time across newspapers } \\
Paper & $\underline{1965}$ & $\underline{1975}$ & $\underline{1989}$ & $\begin{array}{r}\text { Row } \\
\text { total }\end{array}$ \\
The New York Times & 8 & 27 & 56 & 91 \\
Washington Post & 15 & 62 & 164 & 241 \\
Chicago Tribune & 65 & 50 & 181 & 296 \\
Los Angeles Times & 11 & 30 & 67 & 108 \\
Column Total & 99 & 169 & 468 & 736 \\
& & & & \\
& & $\mathrm{X}^{2}(6, \underline{\mathrm{N}}=736)=37.17, \mathrm{p}<.005$ & \\
\end{tabular}


Photos of both men and women over time across newspapers

\begin{tabular}{|c|c|c|c|c|}
\hline Paper & $\underline{1965}$ & $\begin{array}{l}\text { Time } \\
1975 \\
\end{array}$ & $\underline{1989}$ & $\begin{array}{l}\text { Row } \\
\text { total }\end{array}$ \\
\hline The New York Times & 30 & 17 & 49 & 96 \\
\hline Washington Post & 61 & 40 & 87 & 188 \\
\hline Chicago Tribune & 40 & 21 & 138 & 199 \\
\hline Los Angeles Times & 47 & 40 & 73 & 160 \\
\hline Column Total & 178 & 118 & 347 & 643 \\
\hline
\end{tabular}

Total photos over time across newspapers

\begin{tabular}{|c|c|c|c|c|}
\hline Paper & $\underline{1965}$ & $\begin{array}{l}\text { Time } \\
1975\end{array}$ & $\underline{1989}$ & $\begin{array}{l}\text { Row } \\
\text { total }\end{array}$ \\
\hline The New York Times & 120 & 101 & 262 & 483 \\
\hline Washington Post & 165 & 162 & 370 & 697 \\
\hline Chicago Tribune & 309 & 208 & 461 & 978 \\
\hline Los Angeles Times & 213 & 138 & 213 & 564 \\
\hline Column Total & 807 & 609 & 1306 & 2722 \\
\hline
\end{tabular}


Ads for women over time across newspapers

\begin{tabular}{lrrrr}
\multicolumn{1}{c}{ Paper } & $\underline{1965}$ & $\underline{1975}$ & $\underline{1989}$ & $\begin{array}{r}\text { Row } \\
\text { total }\end{array}$ \\
The New York Times & 63 & 51 & 30 & 144 \\
Washington Post & 517 & 273 & 119 & 909 \\
Chicago Tribune & 137 & 119 & 48 & 304 \\
Los Angeles Times & 382 & 266 & 136 & 784 \\
Column Total & 1099 & 709 & 333 & 2141 \\
& & & & \\
& $\mathrm{X}^{2}(6, \underline{\mathrm{N}}=2,141)$ & $=24.51, \mathrm{p}<.005$ &
\end{tabular}

Ads for women and men over time across newspapers

$\begin{array}{lllll} & & \text { Time } & & \text { Row } \\ \text { Paper } & 1965 & \underline{1975} & \underline{1989} & \underline{\text { total }}\end{array}$

$\begin{array}{lllll}\text { The New York Times } & 108 & 41 & 509 & 658\end{array}$

$\begin{array}{lllll}\text { Washington Post } & 255 & 279 & 903 & 1437\end{array}$

$\begin{array}{lllll}\text { Chicago Tribune } & 203 & 241 & 594 & 1038\end{array}$

$\begin{array}{lllll}\text { Los Angeles Times } & 270 & 235 & 663 & 1168\end{array}$

$\begin{array}{lllll}\text { Column Total } & 836 & 796 & 2669 & 4301\end{array}$

$$
\mathrm{X}^{2}(6, \underline{\mathrm{N}}=4,301)=115.80, \mathrm{p}<.005
$$




\begin{tabular}{|c|c|c|c|c|}
\hline \multicolumn{5}{|c|}{ Total ads over time across newspapers } \\
\hline Paper & $\underline{1965}$ & $\begin{array}{l}\text { Time } \\
\underline{1975}\end{array}$ & $\underline{1989}$ & $\begin{array}{l}\text { Row } \\
\text { total }\end{array}$ \\
\hline The New York Times & 171 & 93 & 540 & 804 \\
\hline Washington Post & 772 & 558 & 1026 & 2356 \\
\hline Chicago Tribune & 343 & 360 & 649 & 1352 \\
\hline Los Angeles Times & 659 & 551 & 813 & 2023 \\
\hline Column Total & 1945 & 1562 & 3028 & 6535 \\
\hline \multicolumn{5}{|c|}{$\mathrm{X}^{2}(6, \underline{\mathrm{N}}=6,535)=202.16, \mathrm{p}<.005$} \\
\hline
\end{tabular}


Total articles over time in the Chicago Tribune

\begin{tabular}{|c|c|c|c|c|}
\hline \multicolumn{5}{|c|}{ Total articles over time in the Chicago Tribune } \\
\hline Type of Article & 1965 & $\begin{array}{l}\text { Time } \\
\underline{1975}\end{array}$ & 1989 & $\begin{array}{l}\text { Row } \\
\text { total }\end{array}$ \\
\hline Lifestyle & 55 & 45 & 67 & 167 \\
\hline Consumer & 39 & 42 & 35 & 116 \\
\hline Food & 61 & 23 & 0 & 84 \\
\hline Fashion & 49 & 17 & 4 & 70 \\
\hline Social & 132 & 39 & 47 & 218 \\
\hline Entertainment/arts & 126 & 37 & 222 & 385 \\
\hline Syndicated & 83 & 79 & 205 & 367 \\
\hline Politics/other & 5 & 0 & 40 & 45 \\
\hline Column Total & 550 & 282 & 620 & 1452 \\
\hline \multicolumn{5}{|c|}{$\mathrm{X}^{2}(14, \underline{\mathrm{N}}=1,452)=308.22, \mathrm{p}<.005$} \\
\hline
\end{tabular}




\begin{tabular}{|c|c|c|c|c|}
\hline \multicolumn{5}{|c|}{ Total articles over time in the Los Angeles Times } \\
\hline Type of Article & 1965 & $\begin{array}{l}\text { Time } \\
1975 \\
\end{array}$ & $\underline{1989}$ & $\begin{array}{l}\text { Row } \\
\text { total }\end{array}$ \\
\hline Lifestyle & 29 & 52 & 50 & 131 \\
\hline Consumer & 15 & 29 & 65 & 109 \\
\hline Food & 15 & 0 & 2 & 17 \\
\hline Fashion & 28 & 26 & 17 & 71 \\
\hline Social & 484 & 101 & 79 & 664 \\
\hline Entertainment/arts & 58 & 68 & 78 & 204 \\
\hline Syndicated & 87 & 33 & 148 & 268 \\
\hline Politics/other & 7 & 16 & 107 & 130 \\
\hline Column Total & 723 & 325 & 546 & 1594 \\
\hline \multicolumn{5}{|c|}{$\mathrm{X}^{2}(14, \underline{\mathrm{N}}=1,594)=549.05, \underline{\mathrm{p}}<.005$} \\
\hline
\end{tabular}


Total articles over time in the Washington Post

\begin{tabular}{lrrrr} 
Type of Article & 1965 & $\underline{1975}$ & $\underline{1989}$ & $\begin{array}{r}\text { Row } \\
\text { total }\end{array}$ \\
Lifestyle & 82 & 31 & 40 & 153 \\
Consumer & 25 & 31 & 12 & 68 \\
Food & 5 & 3 & 1 & 9 \\
Fashion & 19 & 9 & 15 & 43 \\
Social & 276 & 53 & 48 & 377 \\
Entertainment/arts & 24 & 127 & 254 & 405 \\
Syndicated & 19 & 34 & 113 & 166 \\
Politics/other & 34 & 22 & 100 & 156 \\
Column Total & 484 & 310 & 583 & 1377 \\
& & & & \\
& & $\mathrm{X}^{2}(14, \mathrm{~N}=1,377)$ & $536.44, \mathrm{p}<.005$ & \\
\hline
\end{tabular}




\begin{tabular}{|c|c|c|c|c|}
\hline \multicolumn{5}{|c|}{ Total articles over time in The New York Times } \\
\hline Type of Article & $\underline{1965}$ & $\begin{array}{l}\text { Time } \\
\underline{1975}\end{array}$ & $\underline{1989}$ & $\begin{array}{l}\text { Row } \\
\text { total }\end{array}$ \\
\hline Lifestyle & 30 & 40 & 20 & 90 \\
\hline Consumer & 23 & 18 & 67 & 108 \\
\hline Food & 33 & 9 & 54 & 96 \\
\hline Fashion & 47 & 14 & 26 & 87 \\
\hline Social & 95 & 12 & 211 & 318 \\
\hline Entertainment/arts & 7 & 4 & 84 & 95 \\
\hline Syndicated & 0 & 0 & 4 & 4 \\
\hline Politics/other & 15 & 8 & 30 & 53 \\
\hline Column Total & 250 & 105 & 496 & 851 \\
\hline \multicolumn{5}{|c|}{$\mathrm{X}^{2}(14, N=851)=193.92, p<.005$} \\
\hline
\end{tabular}


Lifestyle articles over time in The New York Times

\begin{tabular}{|c|c|c|c|c|}
\hline Type of Article & $\underline{1965}$ & $\begin{array}{l}\text { Time } \\
1975 \\
\end{array}$ & $\underline{1989}$ & $\begin{array}{l}\text { Row } \\
\text { total }\end{array}$ \\
\hline Personal relationships & 0 & 11 & 4 & 15 \\
\hline Work/work relationships & 10 & 15 & 7 & 32 \\
\hline Child rearing & 20 & 14 & 9 & 43 \\
\hline Column Total & 30 & 40 & 20 & 90 \\
\hline
\end{tabular}

Lifestyle articles over time in the Washington Post

\begin{tabular}{|c|c|c|c|c|}
\hline Type of Article & 1965 & $\begin{array}{l}\text { Time } \\
\underline{1975}\end{array}$ & $\underline{1989}$ & $\begin{array}{l}\text { Row } \\
\text { total }\end{array}$ \\
\hline Personal relationships & 19 & 19 & 2 & 40 \\
\hline Work/work relationships & 24 & 9 & 33 & 66 \\
\hline Child rearing & 39 & 3 & 5 & 47 \\
\hline Column Total & 82 & 31 & 40 & 153 \\
\hline
\end{tabular}


Lifestyle articles over time in the Chicago Tribune

\begin{tabular}{|c|c|c|c|c|}
\hline Type of Article & 1965 & $\begin{array}{l}\text { Time } \\
1975 \\
\end{array}$ & 1989 & $\begin{array}{l}\text { Row } \\
\text { total }\end{array}$ \\
\hline Personal relationships & 27 & 20 & 17 & 64 \\
\hline Work/work relationships & 6 & 11 & 42 & 59 \\
\hline Child rearing & 22 & 14 & 8 & 44 \\
\hline Column Total & 55 & 45 & 67 & 167 \\
\hline
\end{tabular}

Lifestyle articles over time in the Los Angeles Times

$\begin{array}{lrrrr}\text { Type of Article } & \underline{1965} & \begin{array}{r}\text { Time } \\ 1975\end{array} & \underline{1989} & \begin{array}{r}\text { Row } \\ \text { total }\end{array} \\ \text { Personal relationships } & 7 & 23 & 10 & 40 \\ \text { Work/work relationships } & 15 & 16 & 34 & 65 \\ \text { Child rearing } & 7 & 13 & 6 & 26 \\ \text { Column Total } & 29 & 52 & 50 & 131\end{array}$

$$
X^{2}(4, \underline{N}=131)=15.07, \underline{p}<.005
$$




\begin{tabular}{|lcccc|}
\hline \multicolumn{5}{|c|}{ Consumer articles over time in the Chicago Tribune } \\
Type of Article & $\underline{5}$ & Time & Row \\
Health & 5 & $\underline{1975}$ & $\underline{1989}$ & $\underline{\underline{t}}$ \\
Home care/furnishings & 17 & 20 & 32 & 57 \\
Finances/purchases & 17 & 14 & 1 & 26 \\
Column Total & 39 & 42 & 35 & 116 \\
& & & & \\
& $\mathrm{X}^{2}(4, \underline{\mathrm{N}}=116)=47.07, \underline{\mathrm{p}}<.005$ \\
\hline
\end{tabular}

\begin{tabular}{|lcccc|}
\hline \multicolumn{5}{|c|}{ Entertainment articles over time in the Washington Post } \\
Type of Article & $\underline{565}$ & $\underline{1975}$ & $\underline{1989}$ & $\begin{array}{c}\text { Row } \\
\text { total }\end{array}$ \\
Entertainment/arts & 19 & 121 & 249 & 389 \\
Hobbies & 5 & 6 & 5 & 16 \\
Column Total & 24 & 127 & 254 & 405 \\
& & & \\
& $\mathrm{X}^{2}(2, \underline{\mathrm{N}}=405)=20.86, \underline{\mathrm{p}}<.005$ & \\
\end{tabular}


Entertainment articles over time in the Chicago Tribune

\begin{tabular}{|c|c|c|c|c|}
\hline Type of Article & 1965 & $\begin{array}{l}\text { Time } \\
1975\end{array}$ & $\underline{1989}$ & $\begin{array}{l}\text { Row } \\
\text { total }\end{array}$ \\
\hline Entertainment/arts & 121 & 31 & 213 & 365 \\
\hline Hobbies & 5 & 6 & 9 & 20 \\
\hline Column Total & 126 & 37 & 222 & 385 \\
\hline \multicolumn{5}{|c|}{$\mathrm{X}^{2}(2, \underline{\mathrm{N}}=385)=10.10, \mathrm{p}<.005$} \\
\hline
\end{tabular}

Entertainment articles over time in the Los Angeles Times

\begin{tabular}{|c|c|c|c|c|}
\hline Type of Article & $\underline{1965}$ & $\begin{array}{l}\text { Time } \\
\underline{1975}\end{array}$ & $\underline{1989}$ & $\begin{array}{l}\text { Row } \\
\text { total }\end{array}$ \\
\hline Entertainment/arts & 58 & 65 & 59 & 182 \\
\hline Hobbies & 0 & 3 & 19 & 22 \\
\hline Column Total & 58 & 68 & 78 & 204 \\
\hline
\end{tabular}


Social articles over time in The New York Times

$\begin{array}{lccrr}\text { Type of Article } & \underline{1965} & \underline{1975} & \underline{1989} & \begin{array}{r}\text { Row } \\ \text { total }\end{array} \\ \text { Social events } & 37 & 12 & 21 & 70 \\ \text { Engagements/weddings } & 58 & 0 & 190 & 248 \\ \text { Column Total } & 95 & 12 & 211 & 318 \\ & & & \\ \mathrm{X}^{2}(2, N=318)=76.26, p<.005\end{array}$

Social articles over time in the Washington Post

$\begin{array}{lrrrr}\text { Type of Article } & \underline{1965} & \underline{1975} & \underline{1989} & \begin{array}{r}\text { Row } \\ \text { total }\end{array} \\ \text { Social events } & 232 & 50 & 20 & 302 \\ \text { Engagements/weddings } & 44 & 3 & 28 & 75 \\ \text { Column Total } & 276 & 53 & 48 & 377 \\ & & & \\ \mathrm{X}^{2}(2, \underline{\mathrm{N}}=377)=53.95, \mathrm{p}<.005\end{array}$


Social articles over time in the Chicago Tribune

$\begin{array}{lccrr}\text { Type of Article } & \underline{1965} & \underline{1975} & \underline{1989} & \begin{array}{r}\text { Row } \\ \text { total }\end{array} \\ \text { Social events } & 110 & 39 & 6 & 155 \\ \text { Engagements/weddings } & 22 & 0 & 41 & 63 \\ \text { Column Total } & 132 & 39 & 47 & 218 \\ & & & \\ \mathrm{X}^{2}(2, \underline{\mathrm{N}}=218)=103.30, \mathrm{p}<.005\end{array}$

Social articles over time in the Los Angeles Times

Type of Article

$\underline{1965}$

Time

Social events

354

1975

$\underline{1989}$

Row

Engagements/weddings 130

42

77

total

Column Total

484

101

2

490

174

664

$$
\mathrm{X}^{2}(2, \underline{\mathrm{N}}=664)=35.35, \mathrm{p}<.005
$$


Advertisements over time in The New York Times

$\begin{array}{lrrrr}\text { Type of Ad } & \underline{1965} & \underline{1975} & \underline{1989} & \begin{array}{r}\text { Row } \\ \text { total }\end{array} \\ \text { For women } & 63 & 51 & 30 & 144 \\ \text { For men } & 0 & 1 & 1 & 2 \\ \text { For both } & 108 & 41 & 509 & 658 \\ \text { Column Total } & 171 & 93 & 540 & 804 \\ & & & & \\ & \mathrm{X}^{2}(4, N=804)=187.78, p<.005 & \end{array}$

Advertisements over time in the Washington Post

$\begin{array}{lrrrr}\text { Type of Ad } & \underline{1965} & \underline{1975} & \underline{1989} & \begin{array}{r}\text { Row } \\ \text { total }\end{array} \\ \text { For women } & 517 & 273 & 119 & 909 \\ \text { For men } & 0 & 6 & 4 & 10 \\ \text { For both } & 255 & 279 & 903 & 1437 \\ \text { Column Total } & 722 & 558 & 1026 & 2356 \\ & & & & \\ & & & \\ & \mathrm{X}^{2}(4, \underline{\mathrm{N}}=2,356)=612.02, \mathrm{p}<.005 & \end{array}$


Advertisements over time in the Chicago Tribune

\begin{tabular}{|c|c|c|c|c|}
\hline Type of Ad & 1965 & $\begin{array}{l}\text { Time } \\
1975\end{array}$ & 1989 & $\begin{array}{l}\text { Row } \\
\text { total }\end{array}$ \\
\hline For women & 137 & 119 & 48 & 304 \\
\hline For men & 3 & 0 & 7 & 10 \\
\hline For both & 203 & 241 & 594 & 1038 \\
\hline Column Total & 343 & 360 & 649 & 1352 \\
\hline
\end{tabular}

Advertisements over time in the Los Angeles Times

\begin{tabular}{|c|c|c|c|c|}
\hline \multicolumn{5}{|c|}{ Advertisements over time in the Los Angeles Times } \\
\hline Type of Ad & $\underline{1965}$ & $\begin{array}{l}\text { Time } \\
1975 \\
\end{array}$ & 1989 & $\begin{array}{l}\text { Row } \\
\text { total }\end{array}$ \\
\hline For women & 382 & 266 & 136 & 784 \\
\hline For men & 7 & 10 & 14 & 31 \\
\hline For both & 270 & 235 & 663 & 1168 \\
\hline Column Total & 659 & 511 & 813 & 1983 \\
\hline \multicolumn{5}{|c|}{$X^{2}(4, \underline{N}=1,983)=306.78, \underline{p}<.005$} \\
\hline
\end{tabular}


Photos by gender over time in The New York Times

$\begin{array}{lrrrr}\text { Type of Photo } & \underline{1965} & \underline{1975} & \underline{1989} & \begin{array}{r}\text { Row } \\ \text { total }\end{array} \\ \text { Of women } & 82 & 57 & 157 & 296 \\ \text { Of men } & 8 & 27 & 56 & 91 \\ \text { Of both } & 30 & 17 & 49 & 96 \\ \text { Column Total } & 120 & 101 & 262 & 483 \\ & & & \\ & \mathrm{X}^{2}(4, N=483)=17.35, p<.005 & \end{array}$

Photos by gender over time in the Washington Post

$\begin{array}{lrrrr}\text { Type of Photo } & \underline{1965} & \underline{1975} & \underline{1989} & \begin{array}{r}\text { Row } \\ \text { total }\end{array} \\ \text { Of women } & 89 & 60 & 119 & 268 \\ \text { Of men } & 15 & 62 & 164 & 241 \\ \text { Of both } & 61 & 40 & 87 & 188 \\ \text { Column Total } & 165 & 162 & 370 & 697\end{array}$

$$
X^{2}(4, \underline{N}=697)=64.05, \underline{p}<.005
$$


Photos by gender over time in the Chicago Tribune

$\begin{array}{lrrrr}\text { Type of Photo } & \underline{1965} & \underline{1975} & \underline{1989} & \begin{array}{r}\text { Row } \\ \text { total }\end{array} \\ \text { Of women } & 204 & 137 & 142 & 483 \\ \text { Of men } & 65 & 50 & 181 & 296 \\ \text { Of both } & 40 & 21 & 138 & 199 \\ \text { Column Total } & 309 & 208 & 461 & 978\end{array}$

$$
\mathrm{X}^{2}(4, \underline{\mathrm{N}}=978)=124.56, \mathrm{p}<.005
$$

Photos by gender over time in the Los Angeles Times

$\begin{array}{lrrrr}\text { Type of Photo } & \underline{1965} & \underline{1975} & \underline{1989} & \begin{array}{r}\text { Row } \\ \text { total }\end{array} \\ \text { Of women } & 155 & 68 & 73 & 296 \\ \text { Of men } & 11 & 30 & 67 & 108 \\ \text { Of both } & 47 & 40 & 73 & 160 \\ \text { Column total } & 213 & 138 & 213 & 564\end{array}$

$$
X^{2}(4, \underline{N}=564)=75.13, p<.005
$$


Syndicated articles over time in the Chicago Tribune (Consumer articles removed)

$\begin{array}{lrrrr}\text { Type of Article } & \underline{1965} & \underline{1975} & \underline{1989} & \begin{array}{r}\text { Row } \\ \text { total }\end{array} \\ \text { Personal advice } & 11 & 40 & 59 & 110 \\ \text { Child rearing } & 11 & 0 & 2 & 13 \\ \text { Health } & 0 & 28 & 7 & 35 \\ \text { Hobbies } & 39 & 3 & 69 & 111 \\ \text { Fashion } & 22 & 8 & 4 & 34 \\ \text { Column total } & 83 & 79 & 141 & 303 \\ & & & & \end{array}$




\begin{tabular}{|c|c|c|c|c|}
\hline \multicolumn{5}{|c|}{$\begin{array}{l}\text { Syndicated articles over time in the Los Angeles Times } \\
\text { (Child rearing articles removed) }\end{array}$} \\
\hline Type of Article & $\underline{1965}$ & $\begin{array}{l}\text { Time } \\
\underline{1975}\end{array}$ & $\underline{1989}$ & $\begin{array}{l}\text { Row } \\
\text { total }\end{array}$ \\
\hline Personal advice & 22 & 10 & 83 & 115 \\
\hline Health & 7 & 3 & 2 & 12 \\
\hline Consumer & 7 & 0 & 3 & 10 \\
\hline Hobbies & 36 & 20 & 33 & 89 \\
\hline Fashion & 15 & 0 & 5 & 20 \\
\hline Column total & 87 & 33 & 126 & 246 \\
\hline \multicolumn{5}{|c|}{$\mathrm{X}^{2}(8, \underline{\mathrm{N}}=246)=55.58, \mathrm{p}<.005$} \\
\hline
\end{tabular}


Syndicated articles over time across newspapers

(The New York Times removed)

\begin{tabular}{lrrrr}
\multicolumn{1}{c}{ Paper } & $\underline{1965}$ & $\underline{1975}$ & $\underline{1989}$ & $\begin{array}{r}\text { Row } \\
\text { total }\end{array}$ \\
Washington Post & 19 & 19 & 50 & 88 \\
Chicago Tribune & 11 & 40 & 59 & 110 \\
Los Angeles Times & 22 & 10 & 83 & 115 \\
Column total & 52 & 69 & 192 & 313 \\
& & & & \\
& & & &
\end{tabular}

Syndicated articles about hobbies over time across newspaper

(The New York Times removed)

$\begin{array}{lllll} & \text { Time } & & \text { Row } \\ \text { Paper } & \underline{1965} & \underline{1975} & \underline{1989} & \underline{\text { total }}\end{array}$

$\begin{array}{lllll}\text { Washington Post } & 0 & 12 & 11 & 23\end{array}$

$\begin{array}{lllll}\text { Chicago Tribune } & 39 & 3 & 69 & 111\end{array}$

$\begin{array}{lllll}\text { Los Angeles Times } & 36 & 20 & 33\end{array}$

$\begin{array}{lllll}\text { Column total } & 75 & 35 & 113 & 223\end{array}$

$\mathrm{X}^{2}(4, \underline{\mathrm{N}}=223)=49.26, \underline{\mathrm{p}}<.005$ 